\title{
On Physostoma elegans, Williamson, an archaic type of Seed from the Palaeozoic Rocks.
}

\author{
BY
}

\author{
F. W. OLIVER, F.R.S.
}

With Plates V, VI and VII and ten Figures in the Text. CONTENTS.

I. INTRODUCTION

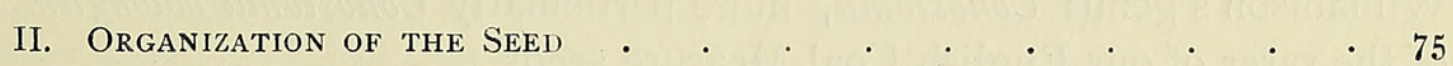

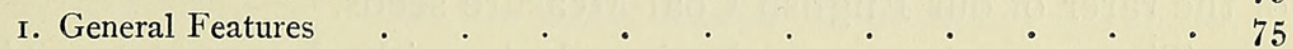

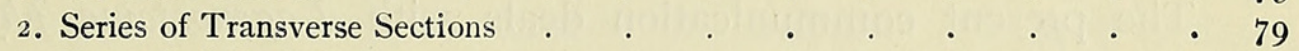

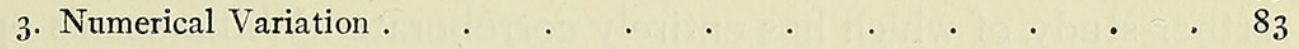

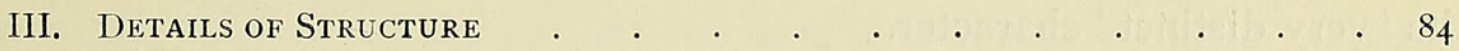

I. The Integument $\quad . \quad+\quad . \quad+\quad . \quad . \quad . \quad . \quad . \quad 85$

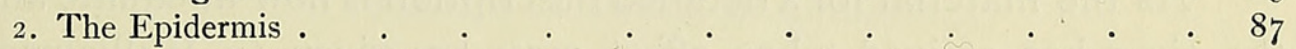

3. The Ground-tissue of the Integument $\quad . \quad$. $\quad . \quad+\quad . \quad . \quad$. 89

4. The Pollen-chamber . . . . . . . . . . . 90

5. Pollination . . . . . . . . . . . . . . . 9 I

6. The Pollen-grains and Spermatozoids . . . . . . . . 93

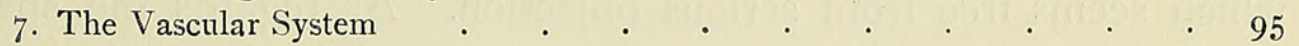

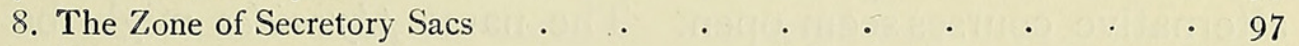

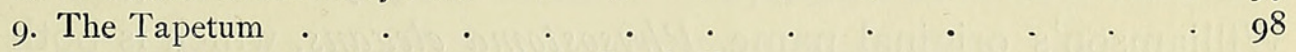

ı. The Megaspore-Membrane and the Prothallus . . . . . . 100

I I. Undersized or Abortive Seeds . . . . . . . . . I

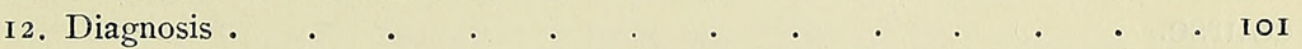

IV. General Discussion . . . . . . . . . . . . . . $\mathrm{IO}_{2}$

I. The Multiple Integument . . . . . . . . . . . - 102

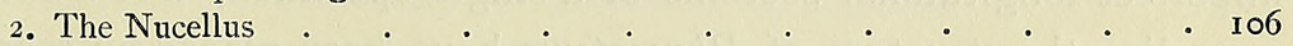

(a) The Zone of Secretory Sacs . . . . . . . . 106

(b) The Tapetum . . . . . . . . . . 106

(c) The Form of the Megaspore-cavity and Pollen-chamber . . I07

3. The Systematic Position of Physostoma . . . . . . . . . 108

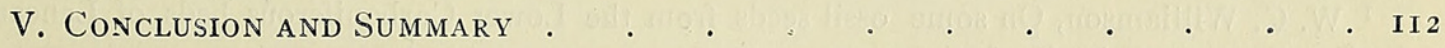

Vi. Explanation of Plates V, Vi, and VII . . . . . . . . . $\quad$ i iz

I. INTRODUCTION.

At the meeting of the British Association at Bristol in 1875 , the late Professor Williamson gave some account of a 'very distinct' petrified seed from the Lower Coal-Measures of Lancashire, for which he proposed the

[Annals of Botany, Vol. XXIII. No. LXXXIX. January, 1909.] 
name Physostoma elegans. ${ }^{1}$ A year or two later, a description of this seed was included by Williamson in his eighth Memoir, ${ }^{2}$ but, owing to the imperfect character of the material at that time available for study, he placed it provisionally in his new genus Lagenostoma, under the name $L$. physoidesthe other member being Lagenostoma ovoides. To these he added in his manuscript catalogue a third species, Lagenostoma Lomaxii, a seed which recent investigation proves to have been borne by Lyginodendron. ${ }^{3}$

In addition to these three species of Lagenostoma-all petrified seeds from the Lower Coal-Measures of Lancashire and Yorkshire-additional species have been discovered preserved as casts. These include the fullydescribed L. Kidstonii and L. Sinclairii, of Arber, ${ }^{4}$ and one or more species discovered by Grand'Eury, ${ }^{5}$ and referred to Sphenopteris Dubuissonis, and other forms. To these casts further reference will be found at p. II 2 of the present paper.

With these seeds must be associated one or more of the species of Williamson's genus Conostoma, ${ }^{6}$ more particularly Conostoma oblongum, one of the rarer of our English Coal-Measure seeds.

The present communication deals with Lagenostoma physoides, the further study of which has entirely corroborated Williamson's opinion as to its 'very distinct' character.

As the material for a detailed description is now adequate and abundant, the time has arrived when effect may be given to Williamson's original intention in the matter of nomenclature. In pursuance of this it is proposed to revive for this seed the abandoned generic name Physostoma, a course which seems free from serious objection. As regards the specific name, alternative courses seem open. The name physoides might be retained, or Williamson's original name, Physostoma elegans, which is both euphonious and appropriate, might be revived. It is proposed to follow the latter course.

Since the appearance of Williamson's description in 1877 , based on two imperfect longitudinal sections of a single specimen, ${ }^{7}$ a few additional facts regarding the structure of Physostoma have been placed on record. Under the name of Sporocarpon ornatum, Williamson described and figured poorly preserved transverse sections of Physostoma in his tenth and twelfth

1 W. C. Williamson, On some ossil seeds from the Lower Carboniferous beds of Lancashire, Brit. Ass. Reports (Bristol) I 875 , p. I59.

2 W. C. Williamson, On the Organization, \&c., pt. viii, Ferns, Gymnospermous Stems, and Seeds. Phil. Trans., I877, p. 24 I.

${ }^{3}$ Oliver and Scott, On the structure of the palaeozoic seed Lagenostoma Lomaxii, \&c., Phil. Trans. B., vol. cxcvii, 1904, p. I93.

- E. A. N. Arber, On some species of Lagenostoma, Proc. Roy. Soc. B., vol. lxxvi, 1 905.

${ }^{5}$ C. Grand'Eury, Sur les graines de Sphénoptéris, etc. Comptes Rendus, t. cxli (I905), p. 81 2.

- Williamson, eighth Memoir, p. 243.

- The sections are in the Williamson Collection, now in the Department of Geology, Natural History Museum, and correspond to the numbers 1439 and 1440. 
Memoirs. ${ }^{1}$ More recently, the late John Butterworth called attention to the ribbed character and hairy covering of the seed, and published photographs of a tangential longitudinal, and of an oblique transverse section. ${ }^{2}$ These photographs are sufficient to establish the identity of Williamson's Sporocarpon ornatum and Physostoma. ${ }^{3}$

\section{ORganization of the Seed.}

\section{General Features.}

Physostoma elegans is a small seed showing considerable resemblance to the Lagenostomas in the general features of its organization. It is a straight, ribbed seed, with a free integument in the apical region; its length from the chalaza to the tip of the multipartite integument reaches $5 \frac{1}{2}-6 \mathrm{~mm}$. - or occasionally a trifle more when the arms are fully extended. In transverse section it is circular, the longitudinal ribs, usually ten in number, giving the outer surface of the testa a sinuous contour. The seed is broadest about one-third up from the base, where its diameter (excluding the hairs which adorn the ribs) just exceeds two millims. The seed is thus a narrow one, broadest somewhat below the middle, and tapering gently towards the apex (Text-fig. I). At the base it is bluntly rounded, so that a median longitudinal section recalls a cuttlefish in miniature.

The central body or nucellus of the seed, which has a length about five-sixths the entire seed, ends in a large apical pollen-chamber. The longitudinally ribbed integument is coalescent with the central body for a distance of about four millims. from the seed-base. Just below the pollenchamber the integument, as a whole, becomes free from the central nucellar body, as in the Lagenostomas, and at once breaks up into about ten arms or tentacles to form a whorl or circlet which loosely surrounds the pollenchamber. The free arms are the direct prolongation of the convex ribs of the testa, or, stated in a slightly different way, the testa forms a ribbed envelope coalescent with the body of the seed throughout its lower twothirds, but free above where the ribs part to form the tentacles.

This replacement of the usual micropylar tube of the integument by separate arms is a distinctive character, in which this seed differs from all other known seeds, fossil or recent. These relations will be understood from a glance at the diagrammatic representations of a longitudinal section in Text-fig. I, taken in conjunction with the series of transverse sections

1 Phil. Trans., I880, p. 5 Io, and P1. XVIII, Fig. 39; Ibid. I883, p. 469, and Pl. XXXI, Fig. 27. In the latter the name is inadvertently cited as Sporocarpon anomalum in the description of the figures on p. 474 .

${ }^{2} \mathrm{~J}$. Butterworth, Some further investigation of Fossil Seeds of the genus Lagenostoma. Mem. and Proc. of the Manchester Lit. and Phil. Soc., vol. xli, pt. iii (I 897).

3 This identification received independent corroboration in a note in the New Phytologist, vol. ii, p. I8 (1903). 
A-D cut at different levels (Text-fig. 2) The photograph of an almost median longitudinal section of the upper portion of a seed (Pl. V, Fig. 4)

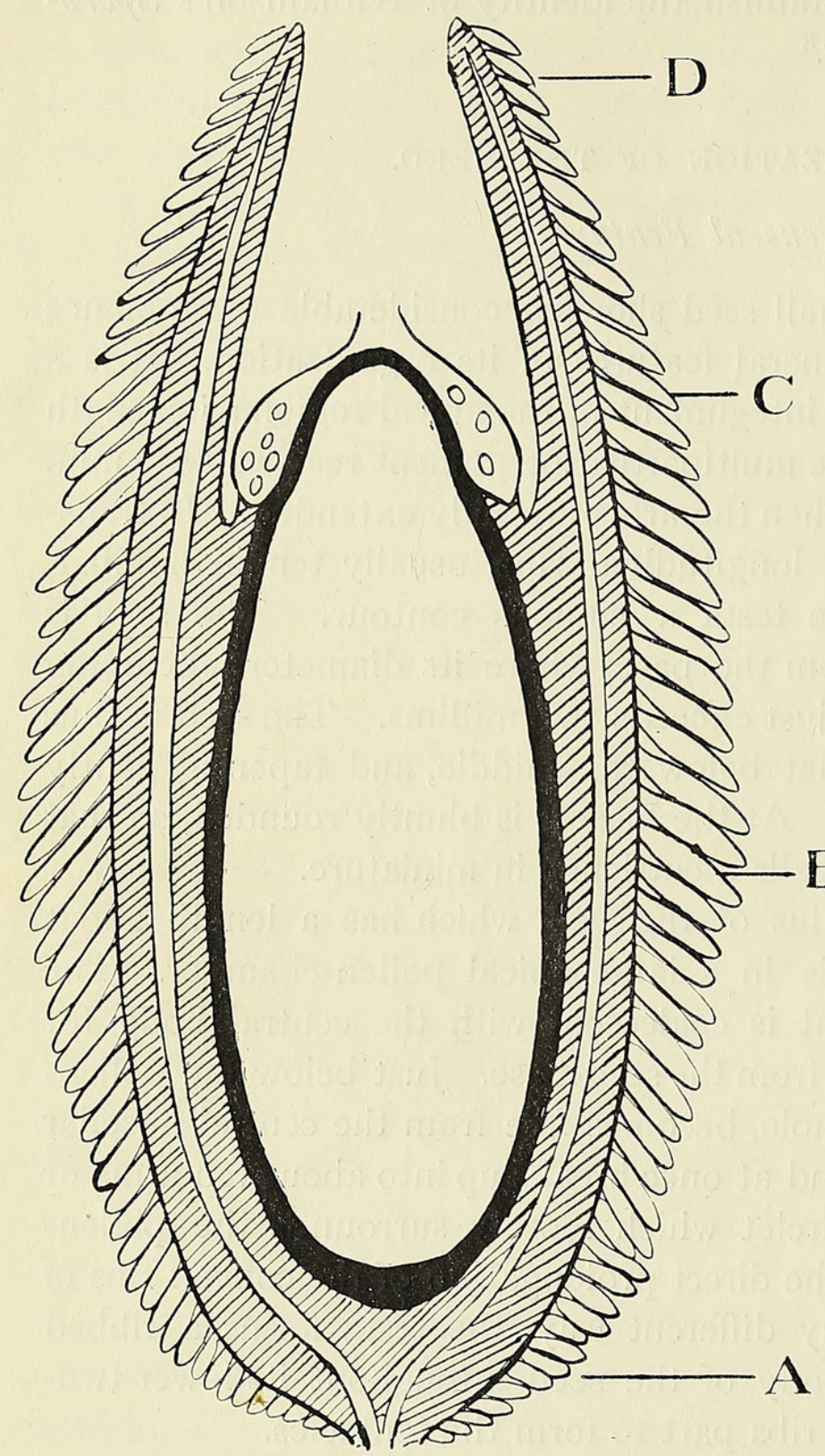

TEXT-FIG. I. Diagrammatic median longitudinal section of Physostoma elegans. The integument is obliquely shaded: the secretory zone is omitted for the sake of clearness, whilst the tapetum is represented as a single layer in black; the vascular strands are left unshaded. The letters A, B, C, and D refer to the heights at which the transverse sections in Text-fig. 2 are cut. shows two of the tentacles cut in the direction of their length $\left(t_{0}\right.$ and $\left.t_{5}\right)$, the insertion of the left-hand tentacle being particularly clear. Four other tentacles, cut transversely or obliquely, are shown at $t_{1}, t_{2}, t_{3}$, and $t_{4}$, immediately above the pollen-chamber $(p)$. Nor should reference be omitted to Williamson's original figure. Published thirty years ago, and based on a rather thick section, this drawing shows the relations of the upper part of the nucellus and tentacles with unerring accuracy, and could hardly be improved upon. ${ }^{1}$

A very striking feature about Physostoma, and one which makes even the smallest fragments easy of identification among the heterogeneous assortment of petrified plantremains that go to form a coal-ball, is the conspicuous investment of long, clubshaped hairs which clothe the summits of the ridges on the body of the seed, and the outer (abaxial) faces of the tentacles. These hairs are commonly to be found with excellent preservation, and reach a length of $5 \mathrm{~mm}$. or more in the neighbourhood of the median line of ridge and tentacle respectively. No doubt, during life, they almost completely enveloped the seed (see the oblique section of an apex, Pl. V, Fig. 8).

\footnotetext{
${ }^{1}$ Williamson, eighth Memoir, Phil. Trans., I877, P1. XI, Fig. 77.
} 
This indeed they still do in the petrifactions in the region of the free arms of the integument, but on the body of the seed they tend to stick together--thus exposing the grooves between the ribs -instead of diverging fan-wise, as occasional examples indicate to have been the position during life (Pl. VI, Fig. I 3). That the investment by the hairs was complete is shown by the very tangentially cut section from the base of a seed given at Pl. VI, Fig. $22\left(t . h_{\text {. }) .}{ }^{1}\right.$ The upper third of the drawing represents the section where, after leaving the tissues of the seed proper, it traverses the covering of hairs in an oblique, upward direction. At the top of the figure, where the section runs through the outskirts, only the longest hairs reach the plane of section.

The vascular system of the seed has essentially the same distribution as in $\mathrm{La}$ genostoma Lomaxii. A supply bundle enters at the rather exiguous seed base, and at once separates into as many strands as there are ribs. The strands run up the seed deep down in the substance of the ribs-at about the level of the intervening grooves-and pass out into the tentacles. No vascular connexions have been traced to the pollen-chamber.

The general ground-substance of the testa is a rather thin - walled, closely - fitting
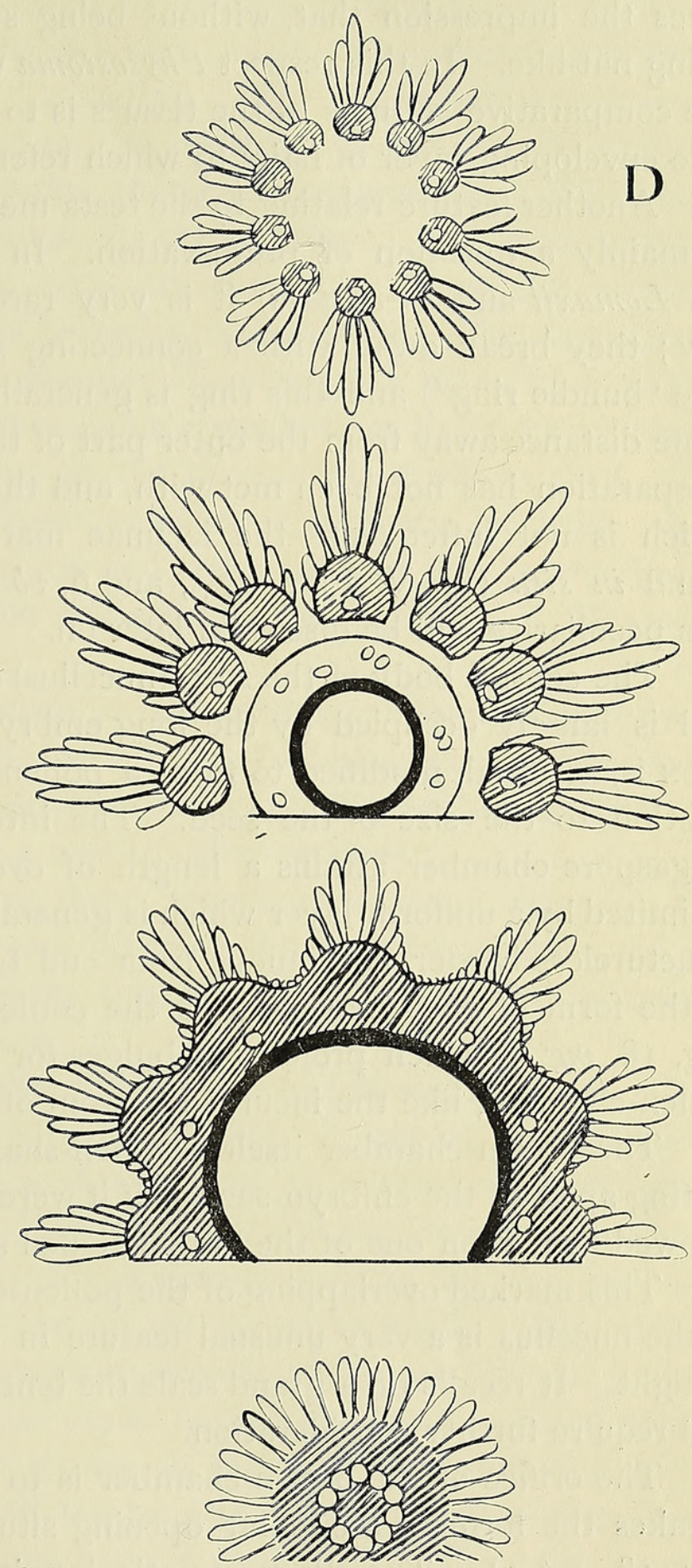

TEXT-FIG. 2. Series of diagrammatic transverse sections of Physostoma elegans. The letters A, B, C, and $\mathrm{D}$ correspond with the heights, in Text-fig. I, to which the sections belong. Shading, \&c., as in Fig. I. tissue of prismatic cells, elongated in a direction parallel to the axis of 
the seed. There is no indication of any general sclerosis, nor is there any localized sclerotic layer such as characterized many of the seeds of the same period. The study of the histological character of the seed-wall gives the impression that, without being succulent, the seed was far from being nut-like. In this respect Physostoma was rather exceptional; perhaps the comparative softness of the tissues is to be correlated with the remarkable enveloping layer of hairs to which reference has been made.

Another feature relating to the testa merits passing comment, though it is mainly a question of preservation. In the case of the Lagenostomas ( $L$. Lomaxii and $L$. ovoides) it is very rare to find the vascular strands in situ; they break away with a connecting sheath of tissue from the testa (the 'bundle ring') and this ring is generally to be found lying contracted some distance away from the outer part of the testa. ${ }^{1}$ In Physostoma such a separation has not been met with, and the bundles, or in their absencewhich is not infrequent-the lacunae marking their position are always. found in situ (Pl. V, Figs. 2, 5, and 6, vb.). The possible explanation of this peculiarity will be discussed later on.

The central body of the seed (nucellus) conforms to the Cycadean type, and is largely occupied by the long embryo-sac or megaspore. The free apex is, as usual, modified to form a pollen-chamber which is very large in relation to the size of the seed. The internal cavity of the nucellus or megaspore-chamber attains a length of over four millims., and is sharply delimited by a uniform layer which is generally preserved as a black, opaque, structureless border, continuous from end to end. A characteristic feature in the form of the embryo-sac is the conical papilla at the apex (Pl. VI, Fig. I $8, m g . p$.$) which projects or bulges for a distance of \frac{3}{4}$ millim. into the pollen-chamber, like the incurved bottom of a wine-bottle.

The pollen-chamber itself is a bell-shaped crevice embracing the projecting apex of the embryo-sac ' as if it were a soft bladder half full of water, allowed to rest on one of the old-fashioned soda-water bottles.' ${ }^{2}$

This marked overlapping of the pollen-chamber and megaspore regions of the nucellus is a very unusual feature in the seeds that have so far come to light. It recalls on a grand scale the tent-pole mechanism of Ginkgo, and will require further consideration.

The orifice of the pollen-chamber is to be found at the summit, where it takes the form of a circular opening situated on a low papilla (Pl. VI, Fig. 18, o.p.c.). The diagrammatic longitudinal and transverse sections, given on pp. 76-77, will serve to epitomize the main relations in the organization of Physostoma.

${ }^{1}$ Oliver and Scott, loc. cit., Pl. VII, Fig. 2, i.s. and Pl. X, Fig. 3I, i.s. and b. r.

${ }^{2}$ Williamson, eighth Memoir, Phil. Trans., 1877 , p. 242. 


\section{Series of Transverse Sections.}

Before proceeding with the detailed consideration of the various regions of Physostoma, the general relations of its organization may be illustrated conveniently by the photographs of a series of three transverse sections cut from a single seed (Pl. V, Figs. I, 2, and 3). That I have had the advantage of studying this series is due to the courtesy of my friend, Professor C. E. Bertrand, of Lille, who, hearing that I was engaged upon Physostoma, placed the preparations in my hands for investigation. The sections, which are numbered M.H. 369,370 , and $37 \mathrm{I}$, traverse the chalaza, the middle of the seed, and the apical circlet of tentacles, respectively. They belonged to the collection of the lamented Maurice Hovelacque, a botanist of marked versatility, who had already made valuable contributions to the knowledge of our English Coal-Measure plants at the time of his death in 1898 . The nodule was doubtless derived from one of our Lancashire localities, whilst the preparation of the sections (carried out with exquisite perfection of technique) was entrusted by the collector to the lapidary, E. Rousseau, of Paris.

The value of the series depends on the fortunate conjunction of excellence of tissue-preservation with a minimum of displacement in the several zones. It is true the layer of epidermal hairs is indifferently preserved, but this defect can be repaired from a host of other sections.

The wall of the seed shows three conspicuous zones, viz.: (1) The integument, extending down to, and including, the vascular strands ; $(2)$ the nucellus, chiefly characterized by the zone of secretory sacs; $(3)$ the tapetal lining, abutting on the embryo-sac.

The main features of the three sections are as follows:-

The lowest section (M.H. 369, Pl. V, Fig. I), cut at a distance of .75 millim. from the base, has a diameter of $\mathrm{I} \frac{1}{2}$ millims. (the epidermal appendages being excluded). The diameter of the internal cavity is .6 millims. It shows the three layers so characteristic of the seed, viz.:-

(I) The integument, some five or six layers in width. This zone is completely separated by a tangentially orientated lacuna (Fig. I, $l$ ) from the subjacent zone throughout the upper half of the section, whilst on the lower half the separation is incomplete in the radii corresponding to the grooves between the ridges. In all, ten lacunae are represented-four below and six above-the latter being tangentially confluent. Where the lacunae are distinct (i.e. below), the surface of the seed is ribbed, where they are confluent the ribbing is obscure (i. e. above). The inner margin of each lacuna contains the vascular strand belonging to its rib (Pl. V, Fig. I, v. b.). Moreover, the tangential intervals between the neighbouring bundles are somewhat smaller on the lower than on the upper half of the section. Evidently the section is slightly tilted, the lower half in Fig. I corresponding 


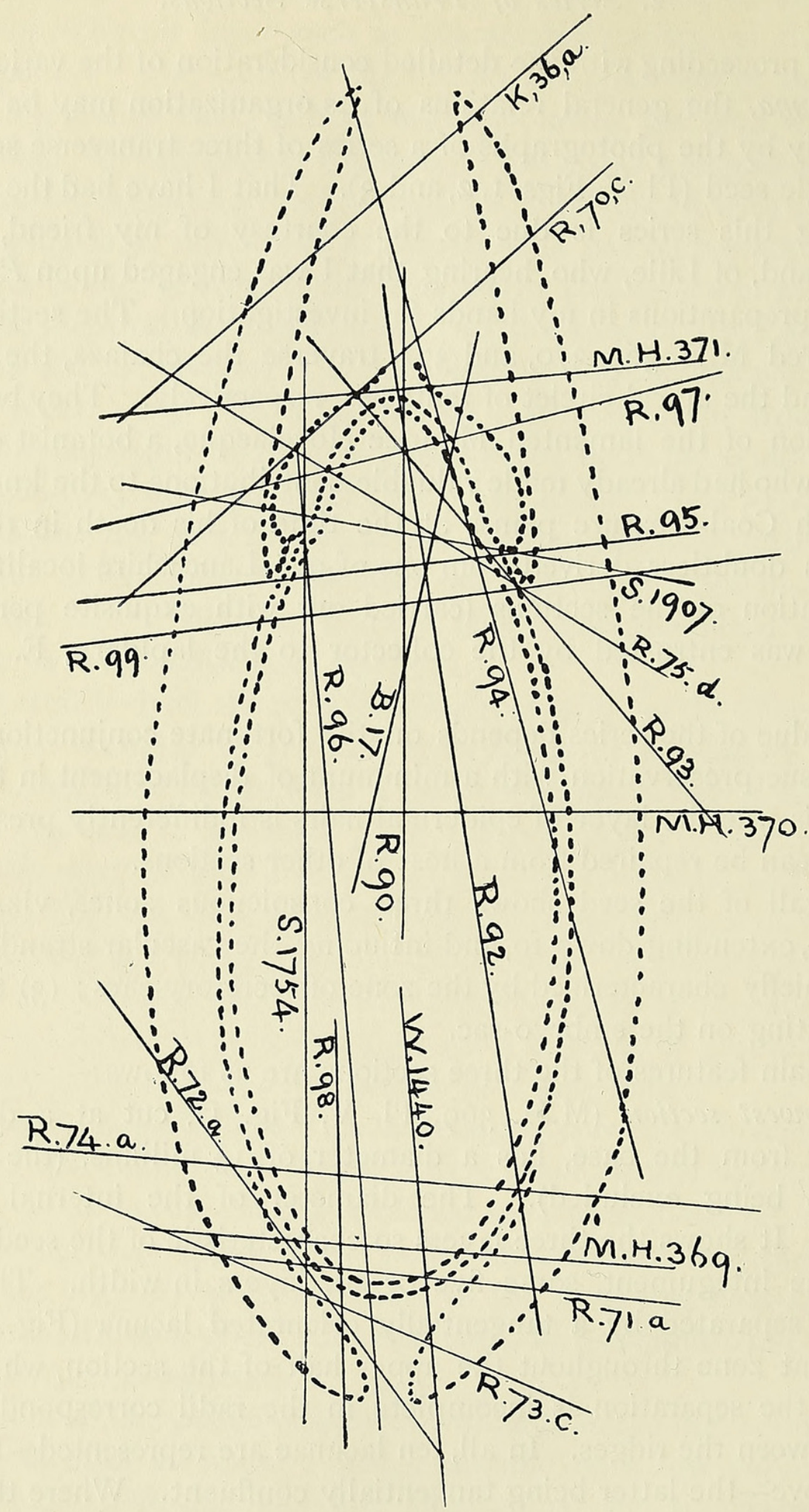

TEXT-FIG. 3. Diagrammatic sketch of a median longitudinal section of Physostoma elegans, upon which are plotted the approximate positions of the planes of section of the principal sections figured in the present paper. The reference letters and numbers given with each section on the figure are the designations under which the preparations are cited in the explanation to the plates W. = Williamson Collection. M.H. = Prof. Bertrand's Collection. S. = Scott Collection. R. and K. = University College, London, Collection. B. = Prof. Bottomley's Collection. 
to a slightly higher level than the upper half. The probable position of this section is plotted in the diagram (Text-fig. 3, p. 80, M.H. 369), the right-hand side of the diagram corresponding to the upper side of the photograph as it is orientated in Pl. V, Fig. I.

This separation of the integument at the seed-base would appear to be of practically universal occurrence in the specimens of Physostoma. The phenomenon is perhaps analogous to the splitting often shown by cut flower-stalks standing in water, which depends on the unequal swelling of the different tissues (cf. Pl. VI, Fig. 2I, l).

(2) Below the plane of splitting is the zone of secretory sacs (s.z.), consisting of a delicate parenchyma in which are scattered great numbers of thin-walled secretory cells, with black, structureless contents. These sacs generally show stretching in the tangential direction. Their longest dimension, however, coincides with the axis of the seed. They are not distributed homogeneously throughout their zone, but have a maximum occurrence midway between the radii occupied by the bundles. At these points the sacs are about five deep, whilst opposite the bundles the number falls to about two.

(3) Within the secretory zone, and bordering the central cavity, is the conspicuous tapetal zone, $\cdot \mathrm{I}$ millim. across, of thick-walled elements with marked radial flattening ( $\mathrm{Pl} . \mathrm{V}$, Fig. I, tp.). Towards the inner limit the cell-cavities are barely visible in consequence of the running together of the thick, black membranes; further out, where the layer abuts on the zone of secretory sacs, the large, tangentially elongated elements become conspicuous.

The second section of the series (M.H. 370, Pl. V, Fig. 2) has a mean diameter of $2 \frac{1}{4}$ millims., whilst the internal cavity has expanded to $\mathrm{I} \frac{1}{2}$ millims.

The three principal zones are recognizable, though their aggregate width shows a slight diminution when compared with the previous section. Of the three, it is the middle (secretory) zone that shows the most conspicuous thinning. The ribbing at the surface is very characteristic. Ten ribs are present lying in the same radii as the ten vascular strands. Separation between the outer and middle seed-zones is restricted to the immediate neighbourhood of the xylem-strands, so that each rib overlies a canal of crescent-shaped or semi-circular section. These canals evidently owe their origin to the breaking down of a delicate tissue that lay just on the peripheral side of the xylem-strands. Between the bundles, the tissues of the integument are in continuity with those of the secretory zone, and at these spots the deeper-seated layers of the integument-and occasionally the more superficial ones as well-show a radial seriation of the cells (Pl. V, Fig. 5, r.f.). In general, it may be remarked that the cells of the outer zone that underlie the furrows show less radial expansion than do those below the ridges. 
The secretory zone, with its now extended perimeter, has thinned out considerably. In the inter-fascicular portions of its course, it shows only a single layer of secretory sacs, whilst beneath each bundle it expands to form a longitudinal cushion in which two ranks of secretory sacs are usually present. It is thus evident that the sacs undergo a rearrangement in the body of the seed; in the previous section their maximum occurrence coincided with the inter-fascicular radii ; here, the reverse is the case.

The elements of the tapetal zone are seen more clearly in this section than in any other that has come under observation. As in the preparation M.H. 369 , the cells are thick-walled and tangentially elongated, but there is less radial compression of the layers as a whole. The outmost of the five layers which it comprises shows clear continuity with the dark rim which marks the inner border of the secretory zone (Pl. V, Fig. 2, tp.). The successive layers of the tapetum show evidence of having been laid down in radial series, though, perhaps in consequence of encroachment by the prothallus within, the radial files have undergone a certain amount of displacement.

What may be regarded as the delicate prothallus-very rarely preserved in Physostoma - is seen in this section lying contracted in the cavity of the seed (Fig. 2, ps.). If the membrane which clothes it be the true megasporemembrane, our seed was very different in this respect from Lagenostoma Lomaxii and $L$. ovoides, in both of which the spore-wall was robustly developed.

The third section of the series cuts the seed at the apex and is slightly tilted in the same sense as its fellow-sections (diagram, p. 80, M.H. 37I). The plane of section falls above the conical apex of the prothallial cavity, the central body of the photograph (Pl. V,Fig.3,p.), being the epidermal shell of the pollen-chamber. The arms towards the lower side of the photograph-of which one (on the left) has slipped out of the circlet-are cut transversely, and show the epidermal hairs on the peripheral side in approximate longitudinal section. In the upper part of the photograph the arms have somewhat greater radial and tangential dimensions, and the epidermal processes have a multiseriate arrangement-appearances that arise from the fact of the tentacles on this side being cut obliquely, and somewhat nearer to the level of their insertion (cf. diagram, p. 80).

Except when clothing the outwardly directed (abaxial) surfaces of the tentacles, the epidermal cells are without tubular processes and have black contents; the epidermis reaches its minimum thickness as it traverses the inside (adaxial) faces of the arms.

The filling tissue of the tentacles consists of a thin-walled, closely-fitting parenchyma which is incomplete towards the inside in consequence of the breaking-down of the vascular strands. Secretory sacs are absent from the tentacles. 
It will be seen from the foregoing general sketch of the organization of Physostoma that, in its fundamental features, it is modelled on such a seed as Lagenostoma Lomaxii. Like Lagenostoma, Physostoma has nucellus and integument coalescent throughout the greater part of their extent; at the apex only, where the nucellus ends in a pollen-chamber, are these organs free. The relations of the vascular supply to the integument are identical in the two cases, and the pollen-chambers have much in common.

The outstanding features of difference in the gross structure of the two seeds are to be found in the free portion of the integument. In Lagenostoma this consists of nine arcs joined together to form a chambered dome-the 'canopy' of Williamson--through the midst of which the tubular orifice of the pollen-chamber projects to the surface. In Physostoma, on the other hand, the canopy is represented by the whorl of free arms; the spatial relations are the same, but fusion is lacking. It is evidently quite inappropriate to apply the term micropyle here, a term designed for an integumental tube leading down to a nucellus and giving access either to pollen-grains or to a pollen-tube. This remark applies with almost equal force to the case of Lagenostoma, where the orifice of the pollen-chamber is produced beyond the surrounding canopy, and must have received the pollen-grains without any assistance from that structure. In dealing with the seeds of such remote ages, the possibility cannot be ignored that features may be present belonging to a period anterior to the evolution of what is termed a micropyle (cf. Text-figs. I, 2, and IO).

The main point to be recognized here is that the tentacles of Physostoma represent the units of the Lagenostoma-canopy in an unfused and, it may well be, in a more primitive condition.

Another point may be mentioned here. Lagenostoma Lomaxii is occasionally found still enclosed in a free, lobed sheath or cupule-like a hazel-nut in its husk. No structure of this kind has been detected in any of the specimens of Physostoma elegans, though the existence of a cupule is not of course excluded. Lagenostoma, with its fairly broad seed-base, had a very effective abscission layer and was shed quite early : Physostoma, with its tapering base, may well have been even more readily detached.

\section{Numerical variation.}

During the course of the present investigation, sections of about fifty specimens of Physostoma have come under observation in which it was possible to count the number of ribs or tentacles.

The result is as follows: Seeds with 9 ribs, 8 ; Io ribs, 25 ; I I ribs, 14; 12 ribs, 6 . Total seeds counted, 53. Two seeds apparently showing 8 ribs were rejected as doubtful. 
The frequency curve embodying these data expressed as percentages has been plotted in Text-fig. 4 .

A similar curve based on countings of the petals of $\mathrm{I} 35^{\circ}$ flowers of Sempervioum Funkii ${ }^{1}$ - which vary round eleven-is placed beside it for comparison. The Sempervivum-curve also represents percentages.

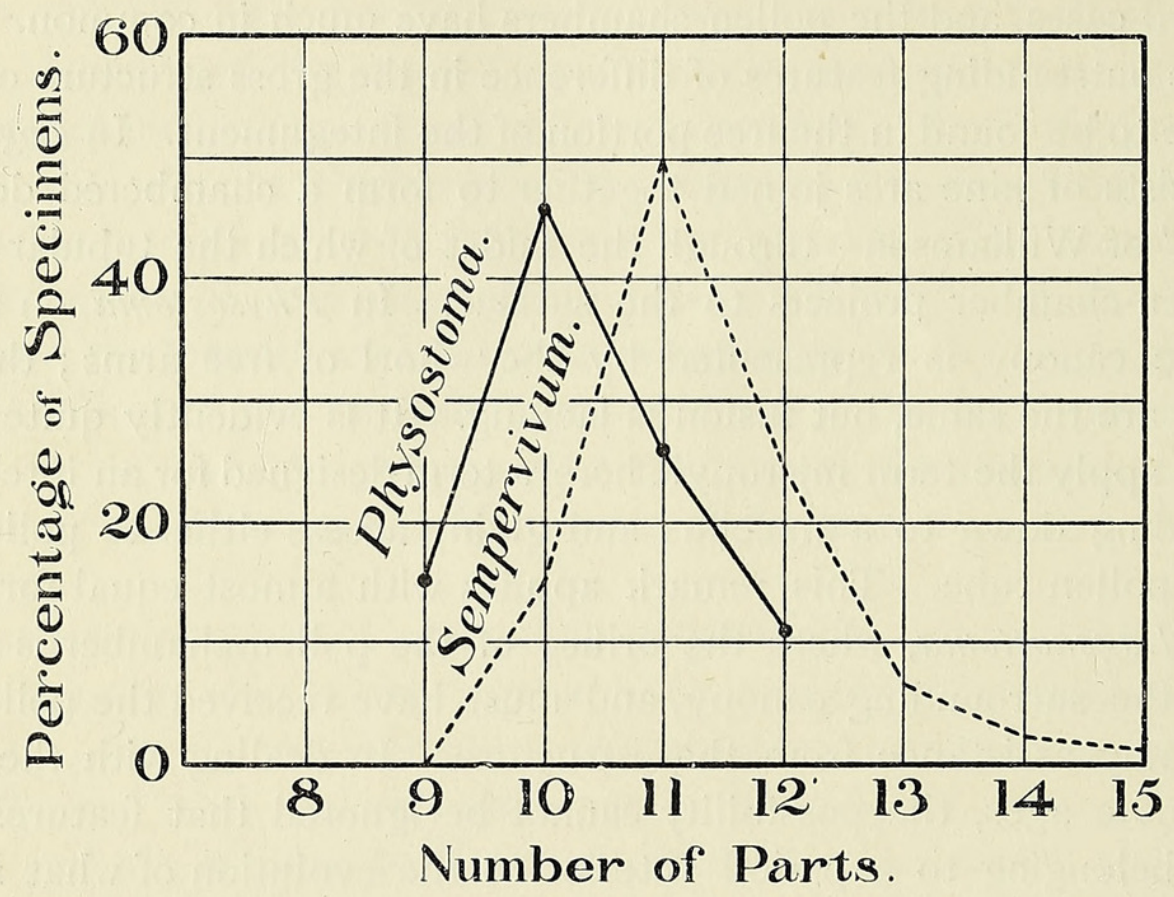

Text-FIg. 4. Frequency curves, representing numerical variation of the ribs in Physostoma (on the left) and of the petals in Sempervivum Funkii (on the right). The numbers are expressed as percentages in both cases.

The close agreement in type between these curves points to the essential identity of the phenomena of numerical fluctuation in palaeozoic times and at the present day.

The various organs and tissue-systems of Physostoma will now be described in detail.

\section{Details of Structure.}

In setting out the structural details of Physostoma, two principal regions are distinguished-the central or sporangial body of the seed and the envelope or integument by which the former is surrounded. These two regions are separate at the apex only; throughout the rest of the seed they are completely confluent.

In a good many seeds of this type the fusion is so complete that no anatomical feature stands out which can serve to indicate the position of the true boundary. In cases of this kind it is convenient to have recourse

1 The Sempervivum-countings have been taken direct from Klebs's 'Ueb. künstliche Metamorphosen', Stuttgart, I906, p. I3. 
to an arbitrary boundary such as is obtained by producing down to the chalaza the plane of separation of the free regions of nucellus and integument. But in Physostoma, as we shall see, the anatomical characters come to our aid and leave us no choice in the matter. The following classification of regions is followed, whilst the grounds on which it is based will be stated in the discussion at the end (p. 106).

The Integument includes the tentacles and the ribbed investment of the seed as far as (but excluding) the secretory zone. The vascular strands belong to the integument.

The Nucellus includes the free apex (of which the peripheral portion forms the pollen-chamber) together with that part of the central body of the seed which lies within the outer limit of the zone of secretory sacs.

\section{The Integument.}

In the foregoing account we have seen that throughout the body of the seed the integument is a ribbed structure fused with the nucellus, whilst level with the pollen-chamber it becomes free, at the same time breaking into a ring of about ten tentacles arranged to form a loose cone around the pollenchamber. Or, starting at the apex, and tracing it downwards, we have a whorl of separate arms which unite laterally with one another at the base of the pollen-chamber. The common tube thus formed almost at once becomes coalescent with the nucellus, and the two run in continuity to the base of the seed. The free arms, however, so far maintain their individuality as to be represented by very distinct ribs traversing the seed in the longitudinal direction. The grooves between the ribs are at first deep, but become shallower as the seed-base is approached-probably dying out at the insertion where the seed tapers to a blunt point (cf. Pl. V, Figs. 2 and I ; Pl. VI, Fig. I3). The common, free tube of joined tentacles-the zone of the seed where there is a continuous free integument-is excessively short and practically negligible. It is only in the case of sections cut horizontally, or all but horizontally, that the existence of such a tube becomes apparent at all. Such a one is Dr. Scott's section through a compressed seed (Scott Collection, 1907), which passes not quite horizontally through the region in question. At the top of the figure (Pl. VI, Fig. I5) - the actually highest part of the section-five arms are already entirely free, whilst at the bottom two are still confluent with each other and with the nucellus. On either side, however, are seen two pairs of tentacles still in tangential continuity, though free from the body of the seed, from which they are separated by a sinus (Pl. VI, Fig. I $5, s n$.). The figure shows the sinus in open communication with the exterior between the free tentacles.

Another section from a slightly lower plane is shown in Pl. VI, Fig. I3. At the top of the figure $(s n$.$) the beginnings of the sinus are apparent. The$ extreme vertical depth of the sinus is found by reference to PI. VI, Fig. I 8 . 
It is at this region, were the section cut in the true horizontal plane, that the relations might be regarded as perfectly comparable to the 'canopy' of a Lagenostoma. Though practically insignificant here, attention is drawn to the fact, as it serves to show how very slight is the readjustment necessary in the mutual relations of the parts to pass from the Physostoma - to the Lagenostoma-condition so far as this particular feature is concerned.

At the level where they are still joined tangentially (Pl. VI, Fig. I3),

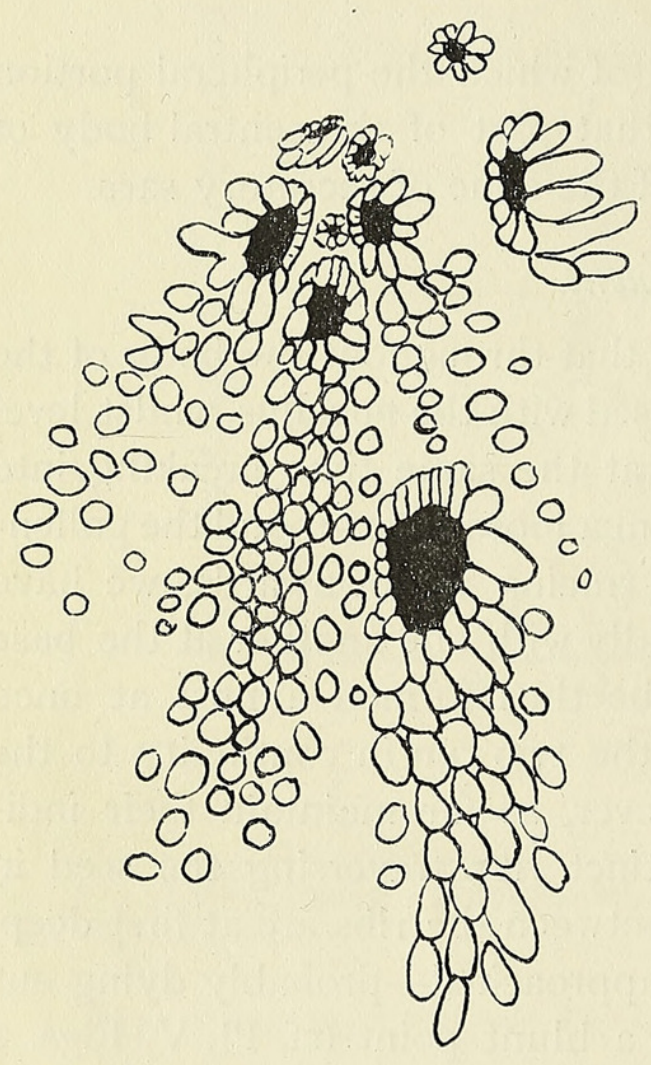

TeXt-Fig. 5. Oblique section across the tip of a seed, above the pollen-chamber. Nine tentacles are shown. Four of the lower ones, cut somewhat tangentially, are subtended by numerous cross-sections of epidermal hairs which were inserted at a lower level. The body of each tentacle is drawn black. $\times 34$. U. C. L., K. $36, a$. the tentacles have a radial diameter of .36 millim., and a tangential diameter of $\cdot 4$ millim. The radial dimension, however, falls almost at once in correspondence with the expansion of the nucellus to form the pollen-chamber, whilst the tangential dimension more nearly holds its own for some little distance, as the bulging wall of the pollen-chamber prevents the whorl of tentacles in this region from contracting its perimeter. Above the pollen-chamber the arms gradually taper, the smallest transverse section of the distal part of an arm that has come under observation having a diameter (inclusive of the epidermis) of $77 \mu$.

The study of numerous longitudinal and oblique sections of the seed shows that the arms may attain a length of 2 millims. from the zone of their insertion - that is to say, their extension beyond the summit of the pollen-chamber is about I millim.

As regards their position, the majority of preparations show the proximal parts of the arms to have formed an enclosure to the pollen-chamber, one deep. Occasional specimens, however, show that one or another of the arms have slipped out of rank as in Prof. Bertrand's section (M.H. 37 I, Pl. V, Fig. $3, t^{1}$ ).

With the distal portions of the arms, more irregularity of arrangement obtains. Sometimes they are found in an untidy bunch-as is well illustrated by an oblique section cut well above the pollen-chamber (Text-fig. 5), the highest that has come under observation. In this figure the interior tissue of the arms is blackened, whilst the epidermis and its appendages are drawn in outline. Four of the nine tentacles-distinguished by their 
trains of satellites-are cut obliquely more or less in the tangential plane, whilst three are cut more nearly at right angles. It is evident that geometric symmetry is lost.

Again, in Pl. V, Fig. 4, the positions of the right and left longitudinally cut arms are quite asymmetrical, whilst the sections of four other tentacles above the pollen-chamber $\left(t_{1} \ldots t_{4}\right)$ show these also to have been in disorder. In contrast to these, others are met with in which the arms preserved a conical posture above the pollen-chamber, as in Dr. Scott's section S. 1753 , W.C. 1440, and a beautiful preparation in Mr. Watson's Collection, prepared with his own hands (Text-fig. 7, p. 92).

The matter need not be pursued further: it is evident the arms afforded adequate protection for the pollen-chamber after pollination had taken place, and it may be conjectured that at an earlier stage they had diverged, permitting access to its orifice. Of this, however, no direct evidence has been found, as almost all our seeds appear to be, approximately, at the same stage of development.

\section{The Epidermis.}

The epidermal system of Physostoma merits detailed consideration on account of the remarkable tubular prolongations into which its cells are drawn out along the convex, outwardly directed faces of the tentacles and ribs - a feature which gives to almost every section of the seed a unique and beautiful appearance.

If a transverse section of a tentacle be examined at the level of the pollen-chamber, such, for instance, as $l$. in Pl. V, Fig. 7 , the flat, centrallydirected face is found to be clothed with a close-fitting layer of small, almost cubical, cells having a radial diameter of about $30 \mu$.

Passing round to the flanks, the height of the cells increases. Many of the cells of intermediate height interlock with corresponding cells on the adjacent tentacles (cf. Pl. V, Fig. 7), thus giving the ring of tentacles in this region much of the character of a united tube. That real fusion is lacking is evident from the readiness with which the tentacles separated without injury to the cells. The interlocking, though less in degree, may be compared to the well-known case of the syngenesious anthers of a Composite flower. In not a few cases among the numerous transverse sections at the level of the pollen-chamber that have come under observation, close contact between the adjacent tentacles did not persist till fossilization, though the close correspondence of the indentations of the epidermal layers show this displacement to be the result of some post-mortem change. Directly the region of contact is passed, the epidermal cells, now much broader tangentially, are found expanded in their full width as large, cylindrical, unicellular hairs or processes with substantial walls which stand out at right angles to the surface of the tentacle. It is along the middle line 
of the convex (abaxial) face of the tentacle that the hairs attain their greatest radial extension; those on the flanks getting shorter and shorter as the region of contact between neighbouring tentacles is approached (Pl. V, Fig. 7).

The relations just described are shown on a larger scale in the sketch of a portion of a transverse section of a tentacle (Pl. VII, Fig. 26, where only the proximal portions of the hairs are given). It is usual to find about seven or eight hairs abreast on the transverse section of a tentacle in its thickest part, but where the section is obliquely cut (as in Pl. V, Fig. 8) this number is of course exceeded.

Although in a majority of cases the adjacent hairs on a rib or tentacle have a tendency to stick together, it is improbable that there was real fusion for a greater distance from the place of insertion than about $75 \mu$. The form of the hairs is subject to some variations. In a fair number of specimens they are club-shaped-the hair tapering to its base. It seems possible that the clavate type corresponds more nearly with the form during life.

As regards their distribution, the hairs are arranged in longitudinally running lines--on the tentacles and seed-body alike. This is clearly shown by an inspection of tangential or very oblique sections through the piliferous layer. In these the successive sections of the individual hairs follow one another in linear series, as shown in Pl. V, Fig. I I, and in Pl. VI, Fig. I6, for the tentacles, and in Pl. VI, Fig. 22, for the body of the seed. In this feature the hairs resemble the cells of the palisade-layer of the testa of Lagenostoma Lomaxii. ${ }^{1}$

With the tapering of the tentacles-as at the level of the summit of the pollen-chamber-first one and then another row of hairs dies out. Those that persist undergo no appreciable contraction as they pursue their way to the tip, though the length of the hairs diminishes. The fine points in which the tentacles end seem to have been without hairs (Textfig. 5 , three of the upper tentacles).

As already stated, the hairs formed an ample covering to the seed, so that its surface during life would at best have been dimly visible along the lines of the grooves.

The contents of the epidermal cells do not always show the same type of preservation. The non-elongated cells of the grooves on the seed-body and of the adaxial sides of the tentacles have, as a rule, blackened contents, but this is not invariable. The hairs, on the other hand, whilst occasionally showing blackened contents, are, in many cases, filled with an opaque yellow matter, which may be homogeneous or vacuolated, or fragmented into granules or larger masses. In the cases in which the secretion does not fill the hairs it occupies a peripheral position. The nature of the secretion that was present in these hairs must remain a matter of con-

1 Oliver and Scott, On Lagenostoma Lomaxii. Phil. Trans. B., vol. 197, p. 205. 
jecture: analogy suggests that it might have been of a mucilaginous character, but at present the investigation of fossilized secretions has been too slight for any confident expression of opinion. It seems probable, however, that we have to deal in this case with a genuine secretion of the protoplasm, rather than with a degradation product of the cell-membrane.

\section{The Ground-tissue of the Integument.}

The Ground-tissue of the Integument consists of closely-fitting, thinwalled parenchyma cells of elongated, prismatic form, the longer dimension being parallel to the axis of the seed. The approximate dimensions of these cells are $200 \mu \times 25 \mu$.

In the case of the tentacles, this tissue forms the whole of the filling substance. It was traversed in the median plane, just below the smallcelled inner epidermis, by a vascular strand, but in the great majority of specimens the strand has broken down, and is represented by an intercellular space (Pl. V, Fig. 7, l.).

In the body of the seed, where integument and nucellus are confluent, there are from five to six layers of these cells, forming an undulating belt (Pl. V, Figs. 2 and 5). The outer layer (upon which the hairs are inserted) and the layer beneath it consist of somewhat larger cells than the deeperlying regions; they often show a slight radial extension.

The cell-contents. The whole of these cells-alike in the tentacles and on the seed-body-show an interior contracted tube, light brown in colour, which on cursory inspection might be taken for a slightly plasmolysed and petrified protoplasmic body (P1.V, Fig. 5, and Pl. VII, Fig. 26, f.t. and Fig. 28). These inner tubes are well seen in most specimens, though, as we shall see, the appearance is not invariable. However striking the resemblance to protoplasmic bodies, it is impossible to accept this interpretation without reserve in the absence of much more critical histological investigations than have yet been carried out upon fossilized cells and tissues. In the present instance this reserve is justified because a certain number of specimens have come under observation which show no inner tubes; moreover, such specimens have the further point in common that the walls of the cells are unmistakably thicker than in the case of the more usual type of preservation (Pl. V, Fig. 9). Hence the possibility is by no means excluded that the inner tubes or vesicles may not be protoplasmic vesicles at all, but rather the lining layers of the cell-wall which have become separated from the main reticulum of cell-walls. In view of these facts it would seem probable that the vesicles in question are really derived from the membrane and not from the protoplasm.

Throughout the body of the seed the interior border of the parenchymazone of the integument abuts upon the very delicate zone in which the secretory sacs are situated-the region usually least well preserved of any 
part of the seed-wall. The salient ribs, of course, overlie the vascular bundles, or, more correctly, the lacunae which are constantly found on the abaxial side of these strands (P1. V, Fig. 6; Pl. VII, Fig. 28). It is only at the base of the seed that these lacunae become confluent tangentially, so that the parenchyma-zone of the testa shows complete separation from the subjacent tissues. (Cf. p. $8 \mathrm{I}$ and Pl. V, Figs. I and 2, for trans. sections; P1. VI, Figs. $2 \mathrm{I}$ and 22, for longitudinal sections.)

Passing from without inwards, except at the seed-base, the tissues follow one another as follows: epidermis, with hair-like prolongations on the ribs; parenchyma of integument; vascular strands; secretory zone; and finally the conspicuous black-walled zone lining the seed-cavity, which may be designated tapetum.

At the base of the pollen-chamber, where the integument becomes free from the nucellus and separates into tentacles, the vascular strands, accompanied by their lacunae, bend out slightly and pass into the tentacles. The secretory zone does not enter the tentacles-indeed, secretory sacs have not been observed either in a tentacle or in the very short united tube above the level at which the nucellus becomes free. The secretory layer and tapetum, both with much diminished radial depth, pass up to the pollen-chamber, clothed externally, of course, by the epidermis which lines the sinus (Pl. VI, Fig. I3).

These layers form the narrow belt or plinth upon which the pollenchamber is seated. This zone measures $\cdot I 5^{-\cdot 2}$ millims. across ; it is simply a zone of nucellar tissue intercalated between the place of separation of the tentacles and the bottom of the pollen-chamber. A similar zone is present in the full-sized seeds of Lagenostoma Lomaxii, where it is considerably more extensive than in Physostoma (.5 millims. across), whilst the slope up to the pollen-chamber is quite gentle, instead of being steep, as in the present case. $^{1} \quad$ (P1. V, Fig. I2, $p l$; Pl. VI, Fig. I8.)

\section{The Pollen-chamber.}

The general features of this organ have already been outlined in the introduction (p. 78). It is a circular chink-like cavity at the apex of the nucellus, formed by the separation of the outer layer (epidermis) which communicates with the exterior by a small circular orifice situated on a low papilla in the axis of the seed (Pl. VI, Figs. I7 and I8, o.p.c.). The extreme dimensions of the pollen-chamber are: Horizontal diameter (outside wall to outside wall) $1.2 \mathrm{~mm}$.; height (from insertion to orifice) $\mathrm{I} \mathrm{mm}$. The corresponding dimensions in L. Lomexii are $.75 \mathrm{~mm}$. and $\cdot 7 \mathrm{~mm}$. The effective cavity of the chamber is restricted to a chink about $37 \mu$ 
wide, owing to the projection into it from below of the apical prolongation of the megaspore and surrounding tissue of the nucellus (Pl. V, Fig. 8, p.c.).

In most specimens the chink widens in its lower half (Pl. VI, Fig. I7), but this condition is probably not the natural one. In Williamson's original section, ${ }^{1}$ and in a very few other specimens, ${ }^{2}$ the central projecting column is buttressed below by a horizontal belt or cushion of tissue-which forms the actual lining of the chamber on its inner side-in such a manner that the width of the chink or lumen remains appreciably uniform throughout (Pl. VI, Fig. I 8, cu.).

As a rule both the inner and outer walls of the pollen-chamber are preserved as black, structureless crusts, so that reliance must be placed on occasional specimens for anatomical details. The outer wall seems to have consisted of cubical cells with rather thick walls (Pl. V, Fig. 3, $p$, the lower side), which doubtless represent the epidermis; whilst in the inner wall, which was several cell-layers in depth, traces of the tapetum overlaid by secretory sacs may occasionally be recognized. The projecting cushion of tissue of the Williamson specimen (W. C. No. 1439) consisted of parenchyma, and that is all that can be said of it. No doubt in life it must have had assigned to it the double function of secreting a collecting drop and of providing for the nutrition of the pollen-grains during their development in the pollen-chamber. Morphologically, this tissue would be the equivalent of the prominent central cone of the Lagenostomas. If the megasporechamber of a Lagenostoma be conceived as invading the central cone tissue, so as to occupy almost the entire space except a residue on the flanks, the resulting relations would closely correspond with the Physostoma-condition.

The orifice of the pollen-chamber is situated on a low papilla at the apex. It is about $\mathrm{I} 50 \mu$ across (Pl. VI, Figs. I7 and 18, o.p.c.). In none of the specimens does the papilla project further than here shown, nor do horizontal sections cut above the pollen-chamber afford any reason for supposing that it is merely the persistent base of a longer beak. If this seed stood alone, it would be quite superfluous even to suspect that a caducous beak had been present ; but when regard is had for the structure of the pollen-chamber in the allied seeds such a possibility must be recognized (cf. p. 92).

\section{Pollination.}

To judge from the quantity of pollen found in the pollen-chamber, the arrangements for pollination in Physostoma must have been unusually efficient. A section across an empty pollen-chamber is the exception. The specimen showing the largest number of pollen-grains that has yet

${ }^{1}$ Williamson Collection, No. I439: figured in his eighth Memoir, Pl. XI, Fig. 77, and P1. XII Fig. $79, h$. The position occupied by the cushion here seems to correspond more closely with the natural condition than in our Fig. 18.

${ }^{2}$ e. g. Scott Collection, No. I 798. 
come under observation came from the collection of Mr. D. M. S. Watson-. prepared by his own hands. To him I am indebted for the opportunity of examining the two longitudinal sections, one median, the other tangential. The former shows seventeen grains in the pollen-chamber, the latter thirty (see Text-figs. 6 and 7). These two sections alone thus retain close on fifty pollen-grains; but the total number present must have been far in excess of this, when it is borne in mind how much of the pollenchamber has been lost in the operations of cutting and grinding.

The questions at once arise: How did the pollen-grains get there? What was the agent of transport, and what were the arrangements at the orifice of the seed for the reception of pollen? As to the last, perhaps we may accept the position of the tentacles shown in the accompanying illustration (Text-fig. 7), based on the median longitudinal section in Mr. Watson's possession. In that case the tentacles behaved collectively

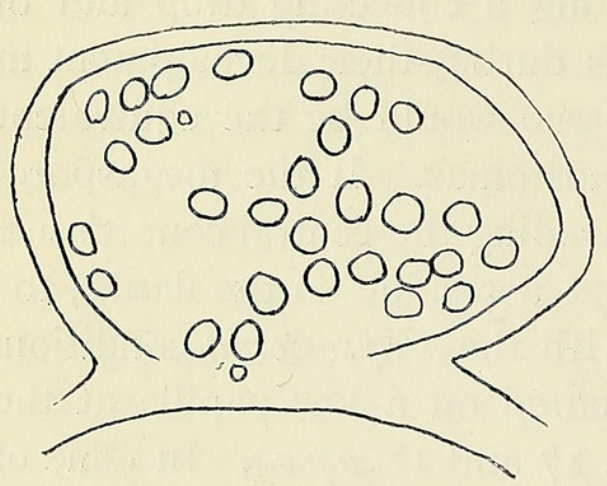

Text-Fig. 6. Tangential section through the pollen-chamber showing about thirty pollen-grains. Sketched from Mr. Watson's preparation. $\times 50$.

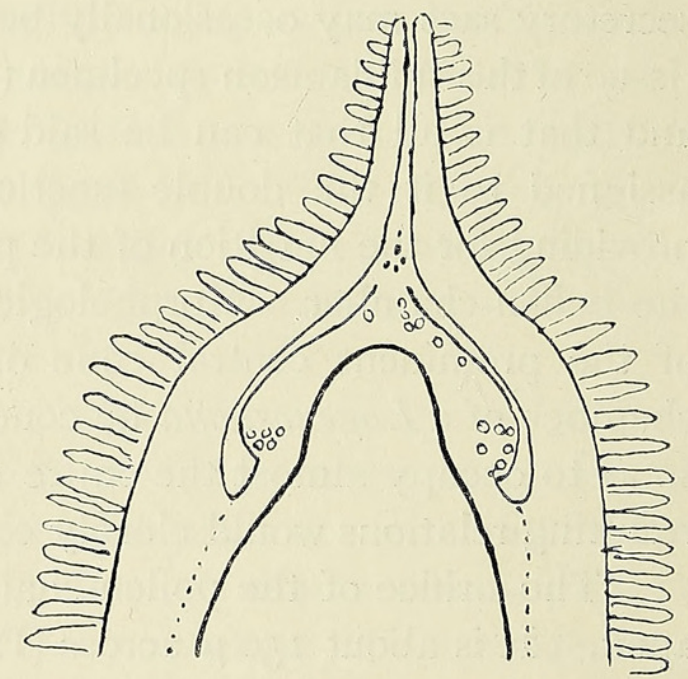

Text-Fig. 7. Sketch of Mr. Watson's median section through the pollen-chamber of Physostoma, showing two arms approximated above the orifice. The dotted lines below the sinus mark where the integument has broken away from the nucellus. $\times 20$ 。

as a closed tube, a micropyle in the making. No doubt a drop excreted from the pollen-chamber played an essential part in the mechanism, as in recent Gymnosperms. That the tentacles formed a close-fitting tube around the pollen-chamber and its orifice is also consistent with the rarity of pollen in the sinus at the base of the plinth. ${ }^{1}$ Whether the 'micropyle' was occupied by a tubular extension of the pollen-chamber--which thus gained direct access to the exterior-remains uncertain. No traces of any such passage have been detected, but in view of the fact that the pollenchambers of both $L$. Lomaxii and L. ovoides had direct access to the

\footnotetext{
${ }^{1}$ Notwithstanding the notable exception described on p. 94.
} 
exterior, whilst that of the allied seed, Conostoma oblongum, was provided with a long tube, constricted or articulated at its insertion, the possibility of the existence of a caducous or non-permanent structure in Physostoma cannot be absolutely dismissed.

If the actual structural details are obscure, so, too, is the agent of transport. The quantity of pollen found in the pollen-chamber suggests an agency of greater precision than mere wind-dispersal, unless the collecting drop at the tip was much more persistent or the load of pollen brought by the wind far greater than is generally the case at the present day. The suspicion is difficult to resist that insects may have been attracted to these seeds in search of the mucilage or nectar or whatever it was that formed the drops. ${ }^{1}$ In the contemporary flora the Pteridosperms must have been relatively important from this point of view, for the Angiosperms, with their superior attractions for insects, had not yet invaded the field. Still, even should this be conceded-that the ovules were visited for their dropsthere would be little result unless the insects had the regular habit of frequenting the pollen-bearing organs, the Telangiums and Crossothecas, of which we know so little. Perhaps, when existing Cycads, Welreitschia, and other Gymnosperms have been more fully studied in respect of their relations to insects, it may become profitable to consider the pollinationmethods of the Pteridosperms. The present discussion will have served its purpose if it lead to attention being directed to the living forms.

\section{The Pollen-grains and Spermatozoids.}

The pollen-grains of Physostoma are ellipsoidal in form, with average. dimensions of $55 \times 45 \mu$. They are the smallest sized pollen-grains met with in the four species of related seeds found as petrifactions in the Lancs-Yorkshire Coalfield. The dimensions of the others are as follows : Lagenostoma Lomaxii, $70 \times 55 \mu$; Lagenostoma ovoides, $70 \times 55 \mu$; Conostoma oblongum, $73 \times 55 \mu$.

Many of the grains of Physostoma show distinct traces of an internal cellular reticulum which recalls that of the pollen of the French seed Stephanospermum akenioides. ${ }^{2}$ An example is represented in the accompanying Text-fig. 8. In view of the observations to be described below, many or most of these internal cells, and especially the larger ones, probably produced each a spermatozoid. Whether

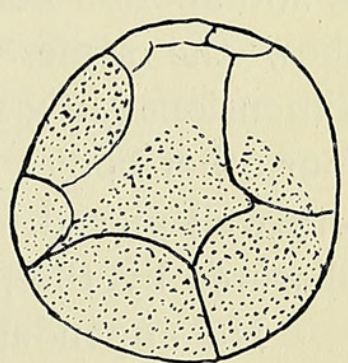

Text-Fig. 8. Pollengrain of Physostoma showing the internal cells. The dotted area is the exospore where it has not been ground away. The grain occurs in Mr. Watson's specimen (Text-fig. 6). $\times 480$. the residuum of smaller cells (of which there is some indication) was prothallial in nature, must remain undecided.

1 The suggestion first came from Sir Joseph Hooker; see Oliver and Scott, On Lagenostoma Lomaxii, Phil. Trans. B., vol. 197, p. 2 I4 (footnote).

2 Oliver, On Stephanospermum. Trans. Linn. Soc., 2nd Ser., Botany, vol. vi, Pl. XLIV, Fig. 33. 
We now come to the question of spermatozoids in connexion with the pollen-grains. Already, in I904, Miss Benson expressed the conviction that the pollen-grains in a specimen of $L$. ovoides in her possession were 'in the act of yielding antherozoids, like those of Cycads and Ginkgo'. ${ }^{1}$ In a recent note, the same writer has described this preparation in some detail. ${ }^{2}$ Four pollen-grains are figured, of which one contains a supposed spermatozoid, whilst another is described as having germinated to form a protruding endospore-something of the nature of a rudimentary pollen-tube. Free in the pollen-chamber there are at least two bodies which the author regards as isolated spermatozoids.

To this example of Lagenostoma ovoides, the present investigation of Physostoma contributes a further instance which merits description.

The specimen is in the collection belonging to the Botanical Department, King's College, London, and I am indebted to the courtesy of Prof. Bottomley for the opportunity of examining it. Here the group of pollengrains is contained, not in the pollen-chamber, but, as occasionally happens, at the bottom of the sinus between the tentacles and the pollen-chamber. Though analogy would indicate that the products of such misplaced grains must fail of their mission to accomplish fertilization, there is no evident reason why the pollen-grains should not continue to develop normally enough, provided the necessary protection and nutriment are forthcoming. In the present case three complete pollen-grains are present (Pl. VI, Fig. 30 , $a, b$, and $c$ ), and what appears to be the remains of the internal cell-reticulum of a fourth $(d)$. The pollen-grain $b$ contains two flattened oval bodies, $c$ contains one; two others are present, one in contact with the reticulum $d$, and another between $d$ and $b$. These five bodies are all clearly defined, show the same type of preservation, are of approximately identical dimensions $\left(20 \times I_{5} \mu\right)$, and have the same sub-reniform outline. In addition, four other bodies are present which are probably of the same nature, but are less well placed for observation. Two are in contact with, and are partly obscured by, the pollen-grain $a$, whilst two lie on the open edge of $c$.

No appendages or cilia have been detected in connexion with these bodies, nor is there any indication of their being limited by cell-membranes. Assuming that the bodies figured are spermatozoids, it would appear from this preparation that they arise within the pollen-grains themselves (Fig. 30, $b$ and $c$ ). The reticulum $d$ would then probably be the remains of a pollengrain from which the exospore had disappeared.

Turning to Miss Benson's specimen of L.ovoides, one of the pollengrains is found to contain a spermatozoid (loc. cit., p. 4IO, Fig. 2, $p^{1}$ ). So far the two seeds are in substantial agreement. But if the sperms arise in

1 Telangium Scottii, Annals of Botany, vol. xviii, p. I68.

${ }^{2}$ M. Benson, On the Contents of the Pollen-chamber of a specimen Lagenostoma ovoides. Bot Gaz., vol, xlv, p. 409 (June, 1908). 
this way, it is difficult to understand the significance of the 'protruding endospore' as figured for L. ovoides (Miss Benson, loc. cit., Fig. 2, $p^{2} e$ ), unless, as seems possible, the full history of these tubes has not yet been recovered. In the case of Physostoma it is, of course, just possible that the cell reticulum $d$ (Fig. 30) may have been carried clear of the grain by the escaping sperms, though there is nothing in the preparation to indicate that $d$ has any relation, except juxtaposition, to the pollen-grain $a$. These, however, are matters on which a decision is impossible till further data are forthcoming.

The point of immediate interest is the detection in two related seeds of bodies whose presence in and about the pollen-grains is difficult to account for except as spermatozoids. The two sets of bodies show a close agreement in occurrence, form, and preservation, whilst the large dimensions of the supposed sperms of $L$. ovoides ( $40 \times 30 \mu$, as compared with $20 \times 15 \mu$ in Physostoma) accords with a similar relation in the size of the pollen-grains in the two cases.

Apart from some quite abnormal product of disintegrating protoplasm, which cannot be profitably discussed, these bodies must be regarded either as organisms parasitic on the pollen-grains, or as petrified spermatozoids, the normal product of pollen-grain development. These and other contemporary seeds are commonly attacked by fungi, and often show the mycelia and vesicles or spores with admirable preservation. ${ }^{1}$ But careful comparison with numerous fungal vesicles that have come under my own observation has failed to convince me that these bodies are to be explained away as fungal productions. Some day, let us hope, expert mycologists may turn their attention to the fungal remains that abound in the petrified tissues of Palaeozoic plants. Till such critical studies are forthcoming a final decision on the nature of these supposed sperms is perhaps not possible. Subject to this reserve, I have no hesitation in expressing the opinion that the case for regarding these naked, sub-reniform bodies as spermatozoids is a strong one. As Miss Benson justly remarks, the discovery of spermatozoids in Ginkgo and the Cycads has paved the way for their detection in the seeds of Pteridosperms. ${ }^{2}$ Now that attention has been drawn to the matter from several quarters, it may be hoped that additional and even more convincing specimens may come to light.

\section{The Vascular System.}

In its fundamental features the vascular system shows agreement with that of Lagenostoma Lomaxii. It may be recalled that in this seed the vascular supply is derived from the chalazal bundle, which enters at the seed-base, by its subdivision into a whorl of nine bundles which range themselves symmetrically around the nucellus, and pass distally into the loculi

1 Cf. Oliver, Notes on Fossil Fungi, New Phyt., vol. ii, p. 49.

2 Miss M. Benson, loc. cit., p. $4^{\mathrm{I}} 2$. 
of the 'canopy' (cf. p. Iog). ${ }^{1}$ Owing to the contraction of the zone of cells along which they run, the bundles in Lagenostoma are very rarely found in situ; commonly they occur attached to a loose sheath which lies about midway between the surface and the axis of the seed. In Physostoma no such displacement is found; the bundles lie in a zone at the inner limit of the tissue of the integument where it abuts on the zone of secretory sacs (nucellus).

Another characteristic feature of our seed is afforded by the course followed by the individual strands as they pass from the chalaza. Instead of arising from the chalazal bundle, relatively high up and near the base of the embryo-sac, these strands are already recognizable at a point not far removed from the actual seed-base. No critical section has come under observation to settle the point whether the vascular supply entered the seed as a single strand, but there are several which show that a ring of contiguous strands surrounding a 'pith' was present very close to the abscission-zone (Pl. VI, Figs. I9, 20, and 2I). These strands, usually ten in number, gradually diverge and make their way to the apex of the seed at the inner limit of the integument. The funnel-shaped 'pith' below the embryo-sac was filled with secretory sacs (see p. 97). At the summit of the seed the strands pass out into the tentacles-one to each.

A great feature in this seed is the system of lacunae that constantly accompanies the strands. At the base, the divergent ring of bundles is surrounded by a continuous annular chink or lacuna (Pl. V, Fig. I). From $\frac{1}{2}$ to $\frac{3}{4}$ of a millim. higher up--where the bundles have reached their full peripheral extension-a single lacuna for each strand replaces this common ring (Fig. 2). These spaces, which are semi-circular or crescent-shaped, lie immediately outside the bundles, and pass with them into the tentacles. They probably originate from post-mortem contraction or decay.

Histologically, the bundles consist of xylem only: no phloem elements have been detected, but it is possible the phloem may have broken down to form the lacunae just described. The xylem strands are extremely delicate and rarely show more than six tracheal elements in any transverse section (Pl. V, Fig. 6 ; Pl. VII, Fig. 28). The largest tracheal elements do not exceed IO-I $2 \mu$ in diameter, except at the chalaza, where they are somewhat tubshaped, whilst $50 \mu \times 30 \mu$ are usual dimensions for the strands. The smallest elements generally occur at or near the outside, so that it is probably correct to describe the xylem-strands as exarch or mesarch. The tracheal elements are for the most part of the delicate, scalariform type (Pl. VII, Fig. 27), though traces of pitted elements have been seen in the chalazal region. An occasional fine spiral element has been found, but the relation of these to the rest of the wood has not been ascertained.

The bundles, after they enter the tentacles, become much attenuated, 
and are very prone to break down without leaving any traces (Pl. VII, Fig. 26). As a matter of fact, tracheal elements are very rarely seen in the tentacles at all, and never, so far as our experience goes, in the more distal parts. By far the most striking feature about the vascular system is its extreme delicacy and liability to break down. From the phylogenetic point of view, the maintenance of the separateness of the bundles to a point very close to the seed-base is of interest. Taken in connexion with the ribs and tentacles of the integument, it is reasonable to regard this peculiarity in the arrangement of the vascular supply as relatively archaic. For if the integument originated as a whorl of separate outgrowths beneath the nucellus, these outgrowths would have, primitively, each its separate vascular supply. The point is further discussed at p. 105.

\section{The Zone of Secretory Sacs.}

This layer would seem to have been the most delicate region of the seed, and the details of its structure can be studied only in the best preserved specimens. Lying immediately within the ring of vascular strands, and abutting upon the tapetum within, this zone stretches from the chalaza to the apex of the megaspore cavity. It is broadest at the seed-base where it may reach I $20 \mu$ across (Figs. I and I 4), whilst over the body of the seed it hardly exceeds $60-70 \mu$ beneath the ridges (Fig. 2). At the apex it closely invests the megaspore cavity, and appears never to run out into the free arms or tentacles of the integument. For reasons given at p. 106, the secretory zone is regarded as representing the nucellus.

Histologically, the zone consists of delicate thin-walled cells, flattened in the tangential plane, the dark sacs mingled with clear parenchyma. On the transverse section the number of sacs on any radius ranges from one or two to five or six. Radial sections of the seed-wall show that the sacs often run in longitudinal seriation. The sacs are thin oblong cells of tabular form with the following average dimensions: length $60 \mu$; radial diameter, $8-10 \mu$; tangential diameter, $50-60 \mu$. They contain a black, structureless secretion, recalling that of the similar sacs in Lyginodendron.

As already stated, the zone of sacs lies within the vascular system of the seed. At the chalaza the entire funnel-shaped space-limited above by the embryo-sac, and on the flanks by the divergent vascular strands-is occupied by crowded sacs (Fig. I9, s.s.). The edge of this funnel is continued so as to enclose the embryo-sac, and for a short distance the secretory zone is seen at its maximum width (Fig. 14, s.z.). The principal accumulations of sacs in this region lie between, and usually project somewhat beyond, the vascular strands. At these spots the sacs may be counted as many as six deep (Pl. V, Fig. 1), whilst beneath the strands they are not more than two deep. These relations only obtain, however, to a distance of about a millim. from the seed-base, giving place gradually to the arrangement typical of the 
greater part of the seed-body. There is a marked thinning out of the sacs between, and a corresponding accumulation beneath, the bundles. The secretory zone thus forms for the most part a thin mantle with thicker ribs or cushions underlying the bundles (Pl. V, Fig. 5, s.z.). These relations hold till the zone is reached at which the integumental arms break away from the nucellus. As the arms separate, their tissues become quite free of secretory sacs (Pl. VI, Fig. I3). The zone of sacs is continued in the nucellus right round the tip of the embryo-sac, though it cannot as a rule be separated from the tapetum, with which, in this region, it forms the black, structureless crust, so characteristic of the generality of specimens $(\mathrm{Pl} . \mathrm{V}$, Fig. 8). Occasional specimens show, however, that several layers of sacs are present immediately outside the tapetum. The narrow zone which tapers up to the pollen-chamber (the 'plinth') is clothed by a small-celled epidermis which separates at a slightly higher level from the tissue within, to form the wall of the pollen-chamber.

\section{The Tapetum.}

Within the zone of secretory sacs the megaspore-cavity is limited in most specimens by a broad, black, structureless crust which reaches a width of $100 \mu$. This layer, which lines the embryo-sac throughout, is so intimately consolidated with the secretory layer in the free apex of the nucellus, that the two together form the structureless, carbonized cone which serves as the hollow, dome-shaped core upon which the pollen-chamber is seated (Fig. I7).

In other specimens, however, the black layer is often frayed out on the inner concave side, so as to present the appearance of a number of black rods inserted at right angles to the direction of the layer as a whole, whilst in yet others this condition co-exists with a definite cellular structure on the side abutting on the secretory layer (Pl. VI, Fig. ${ }^{2} 3, t p^{3}$, and Pl. VII, Fig. 28).

Transitional cases such as these lead up to the condition found but rarely and only in the best preserved specimens, of which Professor Bertrand's series affords an admirable example. Here the zone referred to consists of some six or more radially compressed layers, of which the innermost show the maximum compression, whilst the outermost--that abutting on the secretory zone--has resisted, or not been subjected to, compression (see Pl. V, Figs. 2 and 5, tp., Pl. VII, Fig. 24).

This zone when preserved is composed of rather large cells with blackened walls but without contents. Though the successive layers have undergone displacement in the process of compression, it is probable that they stood in radial files, as suggested by Professor Bertrand's section, M. H. 370 (Pl. V, Figs. 2 and 5) and several others. The U.C. L. sections R, 7 I $a$, and R, $74 a$ (Pl. VI, Figs. 14 and 23, and Pl. VII, Fig. 24) afford corroboration to this view.

Sections such as these prove that both the usual structureless condition 
and that showing radially arranged black rods, are degradation products of a layer comparable, for descriptive purposes, to a zone of corky periderm that has undergone collapse.

Transverse sections near the base of the seed, where the embryo-sac is tapering, show the layer as a broader zone (as in M. H. 369, Pl. V, Fig. I) than is the case higher up; whilst in appropriate sections still nearer the chalaza, the tapetum appears to fill the whole cavity of the seed (PI. VI, Fig. 14, tp.).

It is very rare indeed to find this layer with structure preserved in the region of the pollen-chamber ; the specimen figured in Pl. VII, Fig. 25 , is an exception to the general rule. It is a somewhat oblique transverse section across the apical cone of the nucellus and pollen-chamber; and although the tapetum (which alone is figured) shows a long tangential rift, the layer shows substantial agreement in structure with that found in other parts of the seed.

The compression and poor preservation of the tapetum afford some ground for the supposition that its full functional activity corresponded to an earlier stage in the development of the seed than the one to which the majority of specimens of Physostoma belong. This supposition finds support in certain small-sized seeds or ovules of Physostoma, of which two specimens have come under observation. In these specimens the dimensions are about three-quarters the normal size, and the general preservation has something in common with the interesting little seed of Lagenostoma Lomaxii. ${ }^{1}$

A transverse section of one of these small specimens is represented in Pl. VII, Fig. 29, and the principal feature shown is the tapetum (tp), which, partly separated from the outer wall and contracted in stellate manner, is an extraordinarily conspicuous object. It is reasonable to suppose that this specimen, which shows other peculiarities (cf. p. IOO), represents a considerably younger stage in development than the generality of specimens.

It seems probable that a tapetal layer may have been a common feature in the seeds of the Lagenostoma-group. For in addition to Physostoma, occasional specimens of another seed, the rare Conostoma oblongum of Williamson, inow undergoing reinvestigation, show a well-developed tapetal zone resembling that of Physostoma, whilst a reexamination of the young seed of Lagenostoma Lomaxii raises the question whether the black-walled 'pipes' (there regarded as the shrivelled nucellus and megaspore wall) may not represent a tapetal layer in a state of collapse. ${ }^{2}$

The available information as to the occurrence of tapetal layers in the Lagenostoma-group of seeds may be shortly summarized as follows :Physostoma and Conostoma oblongum had a many-layered tapetal zone,

1 Oliver and Scott, On Lagenostoma Lomaxii, Phil. Trans., B., vol, 197, p. 212.

2 Oliver and Scott, loc. cit., Pl. X, Fig. 34, i.s. 
which, though it often persisted to a fairly late stage in the history of the seed, probably culminated functionally at a somewhat younger stage than that which most of our specimens have reached (as in R. 99, see Pl. VII, Fig. 29). Its persistence may have been facilitated by suberization of the membranes, as Thomson has shown in the case of recent Cycads and other Gymnosperms. ${ }^{1}$ In Lagenostoma, on the other hand, a tapetum has not been detected in the ordinary pollinated specimens; so that, if one were present at all, its functional culmination must have occurred at a much earlier stage of seed-development.

\section{I0. The Megaspore-Membrane and the Prothallus.}

Throughout the investigation of Physostoma careful search has been made for traces of the megaspore-membrane. In the majority of specimens this structure is conspicuous by its absence, and it is only in the rarest examples that a very delicate membrane has been found delimiting the prothallus (as in Professor Bertrand's specimen, M. H., 370, Pl. V, Fig. 2, mg). Though the evidence is mainly negative, the conclusion is difficult to resist that no robust membrane such as occurs in Lagenostoma (both species) was yet present in these seeds when they dropped and were petrified. In this connexion it is of interest to note that in Conostoma oblongum also--which like Physostoma has a many-layered tapetum - a megaspore-membrane has eluded observation. Under these circumstances it would appear probable that the megaspore-membrane in these seeds did not thicken so long as the tapetum was in a state of functional activity.

As regards the prothallus, there is nothing to add to the statement that it was a very delicate tissue in the few cases that have come under observation (as in M. H. 370, Pl. V, Fig. I, ps.). Archegonia have not been seen.

\section{I1. Undersized or abortive seeds.}

Two sections of what appear to be specimens of small seeds or ovules have come under observation during the course of the present investigation. As these sections belong to the middle regions of the seed, and their preservation is indifferent, no full account is possible as in the corresponding specimens of Lagenostoma Lomaxi. ${ }^{2}$ There are certain features, however, worth placing on record. The better specimen of the two is contained in the preparation U. C. L., R. 99 (see Pl. VII, Fig. 29). This section seems to be cut a little below the height at which the tentacles were given off. Eleven ribs are present, and they are crowned by tubular hairs (the latter are not shown in the figure). The mean diameter of the section, excluding

${ }^{1}$ R. B. Thomson, The Megaspore-membrane of the Gymnosperms, Univ. of Toronto Studies, Biol. Ser., No. 4 , 1905 .

${ }^{2}$ Oliver and Scott, loc. cit., p. 2 I I. 
the hairs, is $\mathrm{r} .6$ millim., as compared with 2 millims. or more in normal specimens. The most striking feature is the tapetum (Fig. 29, tp.) which was unusually conspicuous and well-developed, and has been referred to on p. 99. The other feature of interest relates to the position occupied by the vascular strands, which is relatively far out in the ribs (Fig. 29,v.b.) as compared with the usual position in full-grown specimens (cf. Fig. 2, v.b.). The most obvious explanation of this apparent anomaly is to be found in the probable immaturity of the deeper layers of the integument. Now if we suppose the layers with radial seriation, that are present in full-grown specimens, especially below the furrows (P1. V, Figs. 5 and 6, Pl. VII, Fig. 28, r.f.), to be the last portion to differentiate, this, combined with a general expansion of the seed, would bring about the necessary readjustment for the shallowing of the grooves; in this way the ribs would become less prominent and the bundles would come to lie relatively deeper as the seed approached maturity. Were the preservation adequate in the specimen under discussion, traces of this inner meristem ought to be visible.

\section{I2. DIAGNOSIS.}

\section{Physostoma (Williamson).}

Straight, ribbed seeds, radially organized, the ribs separating at the summit into a whorl of free arms which surround the pollen-chamber.

The ribbed integument is coalescent with the nucellus as far as the level at which the arms separate.

The summit of the embryo-sac tapers into a papilla which projects into the pollen-chamber as a hollow core, like the bottom of a wine-bottle.

A vascular system enters at the chalaza, dividing at once into separate strands which run along the ribs and out into the arms.

The nucellus contains numerous secretory sacs; a tapetal zone is also present.

\section{Physostoma elegans (Will.).}

' On some fossil seeds from the Lower Carboniferous beds of Lancashire', Brit. Association Reports (Bristol), I875, p. I 59.

Lagenostoma physoides, Will., ' Organization of the Fossil Plants of the Coal-Measures,' pt. viii, Phil. Trans., I877, p. 241, Figs. 77,78 , and 79. Sporocarpon ornatum, Will., loc. cit., pt. x, Phil. Trans., I880, p. 510 and Pl. XVIII, Fig. 39 ; pt. xii, Phil. Trans., I883, p. 469 , and Pl. XXXI, Fig. 27. Sporocarpon anomalum, Will., loc. cit., pt. xii, Phil. Trans, I 883, p. 474 .

Localities : Moorhouse; Dulesgate ; Bacup ; Shore-Littleborough (abundant); Ashton-under-Lyne; Halifax; always in the seam-nodules. Horizon: Lower Coal-Measures. 
Length, 6 millims.; broadest diameter, $2 \frac{1}{4}$ millims. ; the convex faces of ribs and tentacles, which are usually ten in number, are densely covered with tubular hairs reaching a length of $\frac{1}{2}$ millim.

\section{Physostoma Kidstonii, Arber.}

Lagenostoma Kidstonii, E. A. N. Arber, 'On some new species of Lagenostoma,' Proc. Roy. Soc., B., vol. 1xxvi, I905, p. 245, and Pl. I and II.

Length 6 millims.; broadest diam., $2 \frac{1}{2}$ millims.; ribs and apical lobes usually six in number. Known only as casts.

Locality: Stonehill Colliery, Stonehouse, Lanark.

Horizon: Lower Coal-Measures.

\section{General Discussion.}

\section{The Multiple Integument.}

More than one writer on Palaeobotany has drawn attention to the very exceptional condition presented by the free part of the integument of Physostoma. ${ }^{1}$ Comparison with such a seed as Lagenostoma Lomaxi shows that the united canopy finds its homologue in the circlet of free tentacles of Physostoma. The chambered structure of the former becomes intelligible when viewed in the light of the latter, and leads to the irresistible conclusion-finding support in the widest possible range of analogous casesthat priority in this line of descent must be given to an integument of separate, free segments. The numerical excess of the free tentacles of Physostoma over the united chambers of the known Lagenostomas points in the same direction, i.e. to the relatively primitive condition represented by our seed. ${ }^{2}$

If we were fully informed of the range of structure of the integument in the seeds of the Lagenostoma-group, we should doubtless recognize stages of coalescence intermediate between Physostoma and Lagenostoma Lomaxii. Such an intermediate condition may be accepted without much risk of error for the case of L. Kidstonii of Arber, whilst this author's $L$. Sinclairii may be a second example of the same condition. Both of these were ribbed seeds with notched apices, and their recognition tends to remove Physostoma from the very isolated position it would otherwise occupy.

When we come to the question of the origin of such an integument as that of Physostoma, the only point that is obvious is that here, and in the Lagenostoma-group generally, this origin has been a multiple one. In the absence of direct evidence, the morphological nature of the unit structures

${ }^{1}$ Miss M. Benson, On Telangium Scottii, Annals of Botany, vol. xviii, p. I69. D. H. Scott, Progressus Rei Bot., I, p. 2 II.

2 The usual numbers are as follows: Physostoma, ten: Lagenostoma Lomaxi, nine; Lagenostoma ovoides, eight; Conostoma oblongum, seven; Lagenostoma Kidstonii, about six. 
which collectively form the integument is susceptible of the most diverse interpretation. Two views have already been put forward, and as these are fundamentally opposed, and illustrate quite distinct tendencies in morphological interpretations, the matter is of some little interest. ${ }^{1}$ Many morphologists hold that all new structures are really fashioned out of old ones that have undergone a functional change. The petal is a sterilized sporophyll ; the paraphyses of mosses are sterilized antheridia; the cortex of the aecidial fruit in the Uredineae is the reduced product of fertile hyphae. Of this order is Miss Benson's suggestion that the integument of Physostoma has been elaborated by the sterilization of the peripheral sporangia of an ancestral synangium, the central member of which is represented by the nucellus of the seed-a suggestion which is embodied in her synangial theory of the seed. That sporangia may undergo sterilization and persist as paraphyses scattered through the sori is illustrated by many present-day ferns, more particularly by representatives of the Polypodiaceae, as in Polypodium vernucosum, Vittaria rigida, V. Forbesii, and V. angustifolia, Acrostichum aureum, \&c. ${ }^{2}$ Among palaeozoic Protofilices somewhat similar structures have been attributed by Renault to Botryopteris forensis. ${ }^{3}$ In the absence of special investigations elucidating the nature of these curious structures, it may be admitted provisionally that their sporangial derivation seems probable, and that their existence gives plausibility to the synangial theory.

When we turn to cases offering a closer parallel to the seed condition, such as Lepidocarpon and the megasporocarp of Azolla, the facts that have been ascertained are less favourable to the theory. In Lepidocarpon it is difficult to interpret the integument as other than a special production or enation of the supporting bract or sporophyll, whilst in Azolla the nonfunctional sporangia, which are present immediately below the megasporangium, are found to abort during development, whilst the indusium or sporocarp-wall arises as an independent annular upgrowth below the point of insertion. ${ }^{4}$

Cases such as these show clearly enough that the possibility of integuments arising as new or special formations (where seeds and similar structures are involved) cannot be lightly dismissed. The synangial theory though no doubt tenable, is, after all, no more than a hypothesis, which presupposes in the ancestor the existence of the exceptional condition of a synangium in which the peripheral members were ranged symmetrically around a central sporangium, and in which-unlike Azolla - they persist as a sterilized envelope to form the seed-coat.

\footnotetext{
1 Miss M. Benson, loc. cit., p. I6I ; Oliver and Scott, loc. cit., p. 232.

${ }^{2}$ See Hooker's Genera Filicum, Tab. I4, 68 в, 76 в, 77 A, 8I A, \&c.

${ }^{3}$ See Renault, Bassin houiller et permien d'Autun et d'Épinac. Flore fossile, pt. 2, p. 54 .

4 See Goebel's Organography of Plants, Pt. 2, p. 488 , Fig. 325.
} 
It is undeniable that extreme reluctance is frequently shown in interpreting a given structure as a new formation, and no doubt this conservative attitude has much to justify it. But no one will be prepared to maintain that there have never been new departures involving fresh productions in evolutionary history, though he may incline to relegate them to a remote and prehistoric past. Before such a view can be seriously advanced in any given instance it is necessary to establish a strong case on general grounds that such a production is not merely useful-for that could only explain its survival not its origin - but that its apparition is inherently probable under the circumstances.

In considering the special case of the origin of a seed-envelope we do well to bear in mind what commonly happens in analogous cases. Now where there is localized reproductive activity-especially when centred in organs of a more or less persistent character-nothing is more usual than to find associated with it great vegetative vigour involving the parts round about. These manifestations may take the form of sterile, sheath-like upgrowths or pullulations which enclose the reproductive products, or the whole platform upon which the latter stand may be so permeated with growth that the reproductive organs become overarched or immersed. Examples of the former method are furnished by Coleochaete, Chara, numerous Fungi, Red Seaweeds, Liverworts, and the arils of Angiosperms ; of the latter by Fucaceae, Pteridophyte prothalli with immersed archegonia, the perigynous and epigynous flowers of Angiosperms.

The capacity to form such enclosures is of such wide occurrence that Solms-Laubach was inclined to regard it as an indication of a means at the disposal of the plant for reaching a continually increasing complexity of structure. ${ }^{1}$ To emphasize this 'principle', to which he attached importance, Solms-Laubach proposed for it the term 'cupular formation', or, as we may say encasement. Though it may be premature to attempt to define in terms of stimulus and response the precise sequence of events that leads up to encasement, it will be readily admitted that a new departure such as the inception of the seed habit (where provision has to be made for the increased nutritive drain involved by the retention of the gametophyte would be accompanied by nutritive disturbances that might easily favour the appearance of ' new formations'. Once streams of food become diverted to spots where reproductive bodies are to be fed, it is difficult to see how the associated vegetative tissues (which are usually still in an embryonic condition when the reproductive bodies are laid down) are to be excluded from a share of these supplies. If this be granted, we see that the conditions are favourable for encasement, whilst these encasements, if they serve a useful purpose, will tend to be perpetuated.

1 Solms-Laubach, On the Fructification of Bennettites Gibsonianus, Ann. of Bot., vol. v, p. 45 I. 
In view of these considerations it is suggested that the integument of Physostoma may be an example of encasement, a structure, that is to say, whose origin is contemporary with the inception of the seed habit. Here, as in other members of the group, it has become coalescent with the central sporangium. Those seeds which possess cupules, like Lagenostoma Lomaxii and $L$. Sinclairii, according to this view, have undergone a second encasement, though the envelope is much less specialized than in the case of the integument proper. In later groups, such as the Angiosperms where, in addition to two 'normal 'integuments and a carpel, an aril is often present, we have further phases of the same function.

Assuming the view to be well-founded that the integument of the seeds of the Lagenostoma-group was a lobed structure at its inception, it is not without interest to see how far this primitive feature has impressed itself upon the several seeds.

In Physostoma, as we have seen, the tentacles and ribs are the conspicuous feature at the surface, whilst deeper down the vascular strands are in perfect correspondence. In addition to the integument the tissues of the nucellus in the body of the seed are slightly involved, for the secretory zone below the ribs shows more numerous ranks of secretory sacs than occur between the ribs.

Conostoma oblongum stands next to Physostoma. The free part of the integument is united around the pollen-chamber, it is true, but the unitportions show a distinct tendency to separate, and the lines of fusion are often marked by shallow grooves. The body of the seed is smooth and circular in section and without trace of ribbing save at the chalaza, where sharp-angled ridges appear overlying the vascular strands.

In Lagenostoma Lomaxii and L.ovoides the free part of the integument is perfectly united, and the body of the seed smooth throughout. The multiple origin of the integument, however, is well seen in the chambered, free integument-Williamson's 'canopy'-each chamber representing the apex of an original integumental lobe. The vascular strands correspond in number with the chambers of the canopy, though in very occasional specimens their number may be reduced by fusion lower down the seedwall. The little ridges which surround the micropyle, and are conspicuous in some sections-especially in L. Lomaxii-should not be mistaken for the unit-lobes of the integument. They overlie the well-marked septa between the chambers of the canopy, and it is quite possible they owe their prominence to post-mortem contraction or collapse of the filling-tissues of the chambers.

The course pursued by the vascular strands at the chalaza may be recalled here. Whilst in the Lagenostomas a common supply bundle runs up almost to the embryo-sac before the peripheral strands separate out, 
in Physostoma the individual bundles begin to diverge much lower down. It is difficult to resist interpreting the former as the derived, the latter as the relatively primitive condition.

\section{The Nucellus.}

The investigation of Physostoma has brought to light a number of features connected with the structure of the nucellus which cannot be dismissed without consideration.

These include $(a)$ the zone of secretory sacs; $(b)$ the tapetum; $(c)$ the form of the megaspore cavity, and the pollen-chamber.

(a) The Zone of Secretory Sacs. That the secretory zone should be referred, morphologically, to the province of the nucellar wall rather than to that of the integument, seems to follow clearly from the non-continuation of the secretory zone into the free integumental arms. At the place of separation, the bundles and ground-parenchyma pass out into the arms, whilst the secretory zone and tapetum pursue their course into the free nucellar apex.

In view of the general similarity in organization that obtains between Physostoma and the other members of the Lagenostoma-group of seeds, it is of some interest to note that in none of the latter have secretory sacs been observed in the nucellus. For if it be true, as we conjecture, that the whole of this group of seeds belonged to separate but as yet undiscriminated members of the Lyginodendreae, we have in Physostoma the sole representative of the group of seeds which retains in a noticeable way a character that is invariably present in the vegetative organs of the hypothecated seedbearers. As an isolated feature, not much significance would attach to the point ; but it assumes a different complexion when we find it associated with an ensemble of peculiar and primitive characters, as we do in Physostoma.

(b) The Tapetum. As regards the tapetum, so striking a feature in Physostoma, little need be said. Layers of this kind, occupying a position between the sporangial wall and the sporogenous complex, are generally present in the dehiscent sporangia of the archegoniate or spermophytic series, whilst they have been frequently met with in the indehiscent sporangia (ovules) of both Gymnosperms and Angiosperms. Notwithstanding the doubt that has been expressed as to whether these structures can be regarded as really homologous, in view of the diversity of their development ${ }^{1}$ in different cases, the presence of an extensive tapetum in an early seed like Physostoma raises the question whether it may not be a structure inherited from some non-spermophytic ancestor. Data bearing on this point in the oldest known Pteridophytes - the Botryopterideae-are meagre in the extreme, but so far as they go they point to the presence of a considerable

\footnotetext{
${ }^{1}$ Cf. Goebel in Organography of Plants, pt. 2, p. 596.
} 
zone of tissue interposed between the sporangial wall and the spore-complex. Of these perhaps Grand' Eury's Schizostachys grandosus is the most notable example. ${ }^{1}$

(c) The Form of the Megaspore-cavity and Pollen-chamber. The conical prolongation of the megaspore-chamber at the apex is another curious feature which must not be passed over. It vividly recalls in somewhat generalized form the beak-like process of the embryo-sac in Ginkgo,

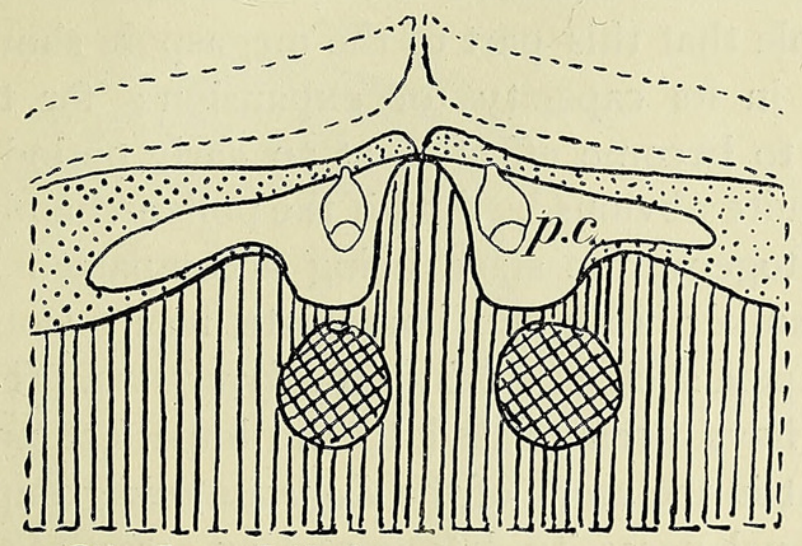

Ginkgo biloba.

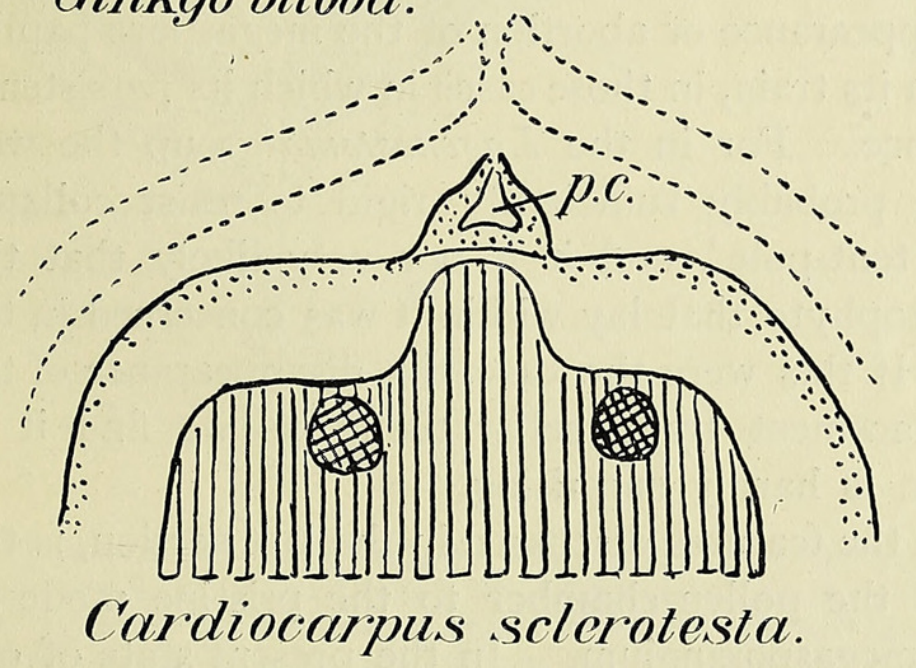

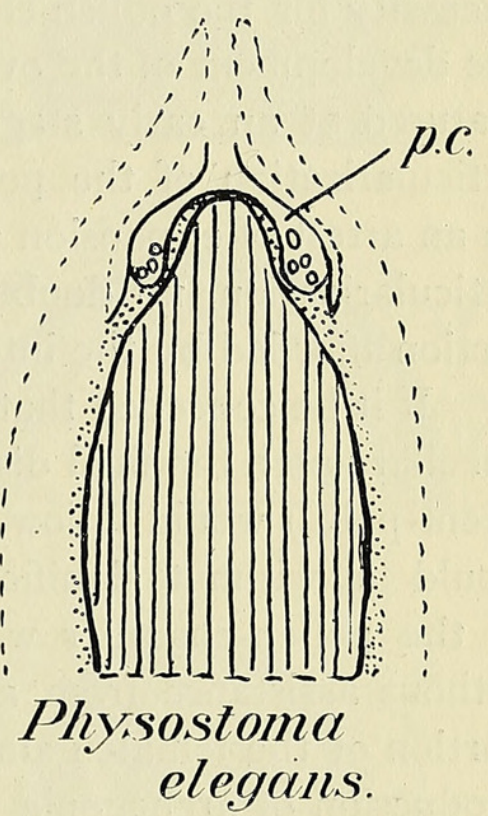

elegails.

Text-FIG. 9. Diagrammatic longitudinal sections of the apices of the ovules of Ginkgo, Cardiocarpus, and Physostoma, showing the 'tent-pole'-like papilla of the megaspore. The gametophyte is represented by vertical lines, the nucellus is dotted, and the integument given in broken outline. わ.c., pollen-chamber.

which Hirasé compared with a tent-pole, holding up the roof of the pollenchamber. ${ }^{2}$ As Scott was the first to point out, a similar structure is found in several Cordaitean seeds. ${ }^{3}$ The interest attaching to this correspondence

${ }^{1}$ Flore Carbonifère, p. 20I, and tab. xvii. $d$ and $d^{1}$, Other cases are enumerated in my 'Vascular Sporangium', New Phytologist. vol. i, pp. 62-3.

${ }^{2}$ S. Hirasé, Études sur la Fécondation, etc. du Ginkgo biloba, Journ. of the Coll. Science, Japan, vol. xii, p. I I 3 , and Pl. IX, Figs. 35 and 36 .

${ }^{3}$ Studies in Fossil Botany, 1900, p. 440. Numerous 'tent-poles' are figured in Brongniart's 'Les graines silicifiées', Pl. II, Fig. 2 ; Pl. V, Fig. 5 ; Pl. VI, Fig. 7 ; Pl. XI, Fig. 4 ; Pl. XII, Figs. I and 2; Pl. XV, Fig. 5. See also Coulter and Chamberlain, 'Morphology of Spermophytes,' pt. i, Gymnosperms, p. I 40. 
in Physostoma arises from the possibility that this seed presents us with the primitive structure of which the ordinary 'tent-poles' (Ginkgo and Cordaites) are surviving representatives-that the apical prolongation of the megaspore-chamber is the primordial tent-pole. In the accompanying Textfig. 9, the three cases referred to are represented, as far as the relations at the apex of the nucellus are concerned.

If the conjecture prove well-founded that the extension of the megaspore-cavity right up to the apex was an archaic trait, derived from a very remote past, it would be intelligible that this part of the megaspore should show relative arrest or atrophy in its capacity for expansion; for the necessity for the pollen-chamber to become effective at an early period in the development of the ovule is quite obvious. ${ }^{1}$ And if the pollen-chamber matured at an early stage in ontogeny, the stage being accompanied by cuticularization of the pollen-chamber wall, the immediate result would be an arrest of expansion at the apex, such as we find in Physostoma. The cuticularization, no doubt, may have been related to the imperfect protection afforded by the integument in the seeds of the Lagenostoma-group. ${ }^{2}$

If it be conceded that functional necessity determined an arrest of the nucellar apex, the final disappearance or abortion of the megaspore papilla ('tent-pole') would follow in its train, in those cases in which its persistence would be without significance. For in the Lagenostoma-group the wall of the pollen-chamber was probably sufficiently rigid to resist collapse without assistance from a 'tent-pole', and it is not very likely that the portion of the female gametophyte that lay within it was concerned in the production of archegonia. If this were the case, the disappearance of the apical process and its replacement by nucellar tissue, as we find it in I. Lomaxii and L. ovoides, is hardly surprising.

Closely bound up with the features discussed in the last section, is the question of the relation of the pollen-chamber to the pristine mode of dehiscence of an ancestral megasporangium. In the present state of our knowledge no data are available that throw any light upon this very important stage in seed-evolution, and under the circumstances discussion would be unprofitable.

\section{The Systematic Position of Physostoma.}

Throughout the preceding account of Physostoma a close relation to the seeds of the Lagenostoma-group has been assumed. Little remains to be said under this head beyond bringing together the scattered references in the text which emphasize the affinity. It should be stated at the outset

1 The small-sized seeds of Lagenostoma Lomaxii possess fully developed pollen.chambers. Cf. Oliver and Scott, loc. cit., p. 2 I 2.

2 The tip of the pollen-chamber protrudes beyond the integument in L. Lomaxii. Cf. Oliver and Scott, loc. cit., Pl. IX, Figs. 2 I and 24. 
that no direct evidence of continuity with vegetative organs has come to light during the course of the investigation, nor have any traces of such structures as a cupule or stalk been detected which might have served indirectly, as in the case of $L$. Lomaxii, to establish such a connexion. The relationship with the Lagenostoma-group depends upon essential similarity in organization between Physostoma and those seeds.

This agreement was evident to Williamson, who thirty years ago had
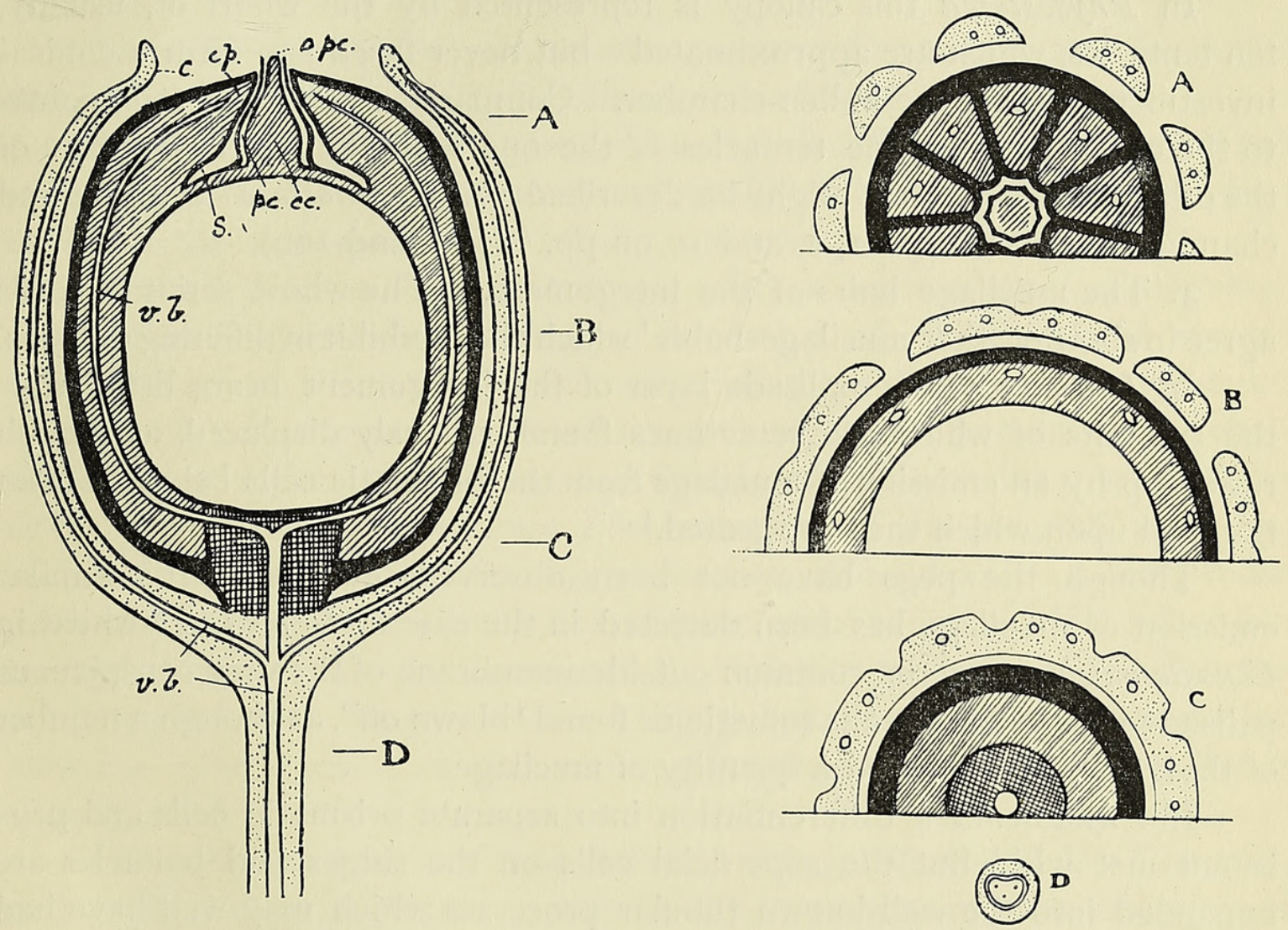

TEXT-FIG. Io. Diagrammatic longitudinal and transverse sections of Lagenostoma Lomaxii. The letters A, B, C, and D show the heights at which the transverse sections are cut. The hard outer layer of the seed-coat is drawn in black; the soft interior tissues obliquely shaded; the chalazal cushion cross-hatched ; the vascular strands are left white; the cupule and stalk are dotted. p.c., pollen-chamber; o.p.c., orifice of pollen-chamber; c.c., central cone; s., sinus; $c p$., canopy; $c .$, cupule ; v.b., vascular strands.

only a single imperfect specimen at his disposal, and further detailed study has served only to strengthen the bonds of resemblance.

The points of agreement between Physostoma on the one hand, and the Lagenostoma-group (which includes $L$. Lomaxii, $L$. ovoides, and Conostoma oblongum) on the other, are as follows:-

I. All the seeds are of that type in which the apex of the nucellus alone is free from the integument.

2. In all cases the free apex is transformed into a crevice-like pollenchamber through the separation of the epidermis from the subjacent tissue of the nucellus. The orifice of the pollen-chamber is apical in position, and is borne at the extremity of a tube of varying length. 
3. The characters of the free portion of the integument or 'canopy'. In $L$. Lomaxii the free portion of the integument forms a chambered shell which surrounds the pollen-chamber. The number of the chambers is nine, and each is penetrated by a vascular strand. In $L$. ovoides the structure is essentially the same, excepting that the number of chambers is usually eight. At the level at which the integument merges with the nucellus its chambered character is lost.

In Physostoma this canopy is represented by the whorl of, usually, ten tentacles, which are approximated-but never fused-to form a conical investment around the pollen-chamber. Comparison of these seeds points to the equivalence of the tentacles of the one with the fused chambers of the others. Physostcma might be described as a Lagenostoma with unfused chambers (cf. Text-figs. I, 2, and Io on pp. 76, 77, and I09).

4. The mucilage hairs of the integument. The whole series of seeds agree in showing the 'mucilage-habit' which they exhibit in differing degrees.

In L. Lomaxii the palisade layer of the integument bears little pegs, the summits of which are sometimes found curiously displaced, as though raised up by an emission of mucilage from the prismatic cells below or from the wall upon which they are seated. ${ }^{1}$

Though the pegs have not been observed, evidence of a similar emission of mucilage has been detected in the case of $L$. ovoides, ${ }^{2}$ whilst in Conostoma oblongum the common outside membrane of the very conspicuous palisade-cells of the testa is sometimes found 'blown off', as though a number of these cells had emitted a quantity of mucilage.

In Physostoma a differentiation into separate prismatic cells and pegs is not met with, but the superficial cells on the ridges and tentacles are expanded into the well-known tubular processes which may well have had a mucilaginous secretion as contents.

The agreement between the several seeds is thus a striking one, and, taken in connexion with the other points of resemblance, is consistent with a derivation of the group from some common antecedent form.

5. The epidermal cells (prismatic cells in L. Lomaxii and ovoides, and the epidermal cells in Physostoma) were arranged in longitudinally-running linear series.

6. The vascular system in all these seeds has essentially the same distribution.

7. The many-layered tapetum of the nucellus or 'megaspore-jacket', so characteristic a feature in Physostoma is also met with in Conostoma; there is also some slight grounds for the suspicion that it may have been present at early stages of development in L. Lomaxii. ${ }^{3}$

${ }_{1}$ Oliver and Scott, loc. cit., Pl. X, Figs. 28, 28 A, 28 B, and Pl. V, phot. I2, and p. 206.

${ }^{2}$ In the specimen R. 22 in the University College Collection, the appearance is identical with that shown for L. Lomaxii, in Oliver and Scott, loc. eit., Pl. V, Fig. I 2.

${ }^{3}$ Cf. p. 99. 
8. The pollen-grains show a general agreement, and internal cells have been detected in all four species.

In Physostoma and L.ovoides, bodies have been found both within the pollen-grains and also associated with them, which there are grounds for regarding as spermatozoids. The form of the supposed spermatozoids is identical in the two cases, and recalls that of Cycas, except that the sperms in the fossils are much smaller, and no trace of the band of cilia has been detected.

The difference in size between the sperms of Physostoma and L.ovoides accords with the difference in the dimensions of their pollen-grains.

These several points of agreement, comprehending all the regions of the seed, appear to be too numerous and striking to admit of interpretation except as the outcome of close affinity, i.e., community of descent.

Whilst it seems evident that in this series of seeds of the Lagenostomagroup, the existence is disclosed of a number of closely-related species of Pteridosperms all occupying the same habitat, a difficulty is encountered when we try to point with any confidence to vegetative remains in our coalnodules that could have belonged to the plants that bore these seeds. Up to the present time Lagenostoma Lomaxii, alone of the petrified seeds, has been definitely correlated with Lyginodendron oldhamium. ${ }^{1}$ Among those preserved as impressions, several cases have come to light. Mr. Arber has referred Lagenostoma Sinclairii and L. Kidstonii to fronds of the Sphenopteris-type $;^{2}$ and Monsieur Grand' Eury has found strong grounds for referring other seeds of the same general character to Sphenopteris Dubuissonis. ${ }^{3}$

The position, therefore, is as follows: One petrified seed (L. Lomaxii), and at least three impressions, superficially in agreement with the seeds of the Lagenostoma-group, have been referred to the frond-type Sphenopteris. We are still left with Physostoma, L.ovoides, and the Conostomas, all petrifactions from the same group, and-excepting for Heterangium-there are no species of Sphenopteris yet separated from Lyginodendron by anatomical characters to which they could be assigned.

The close structural resemblance shown by L. ovoides and L. Lomaxii clearly points to Lyginodendron as their common source-indeed it has long been recognized that a vigorous analysis of the anatomical material that goes by the name of Lyginodendron oldhamium should lead to the discrimination of a group of related forms. The Burntisland species of Conostoma may be dismissed for the moment as probably the seed of Heterangium, in view of its common association in the nodules with the vegetative organs of this plant-to the total or almost total exclusion of

1 Oliver and Scott, loc. cit.

2 E. A. N. Arber, 'On some New Species of Lagenostoma', Proc. Roy. Soc., B., vol. lxxvi, p. 245.

${ }^{3}$ Grand'Eury, loc. cit. 
Lyginodendron. Whether Conostoma oblongum should be referred to the same quarter must remain in suspense till it has been more fully investigated.

As to the parentage of Physostoma, we remain completely in the dark. It is just possible that its vegetative organs are not represented in our nodules. The delicacy of its vascular strands, and the readiness with which the tissues surrounding them gave rise to lacunae, may be significant of a general organization that was unable to resist decay.

Apart from this possibility, the organization of the seed-showing as it does close relationship with the Lagenostoma-group-seems to point to some form with Sphenopteris-foliage as its source. This conjecture is consistent with the facts available regarding $L$. Kidstonii, which, of all the Lagenostomas, shows the closest approach to Physostoma. ${ }^{1}$ Whether the petrified remains of the Physostoma-fronds are included under the comprehensive Lyginodendron oldhamium, and if so whether they are anatomically distinguishable, must remain for future investigation to determine. The Systematist who handles recent plants finds the reproductive and vegetative organs in continuity, and thus escapes much of the perplexity to which the Palaeobotanist is liable. The predicament outlined above is perfectly comparable to that which would obtain with certain genera of recent Cupressineae or Umbelliferae were they only known in a fragmentary state.

In conclusion, it remains to acknowledge help from many quarters. My thanks are due to Prof. C. E. Bertrand for the loan of the unique Maurice Hovalacque series, whilst Prof. Bottomley, Mr. R. Kidston, Dr. Scott, Mr. D. M. S. Watson, and Prof. F. E. Weiss have all placed preparations at my disposal. To Dr. Smith Woodward, of the Geological Department of the British Museum, I am indebted for facilities in examining the preparations of the Williamson Collection. Mrs. D. H. Scott kindly counted the ribs and tentacles of a number of Physostomas in the Scott Collection, thus swelling materially the numbers available for the curve on p. 84. In addition to supplying me with sections of the seed during a number of years, Mr. James Lomax, of Bolton, has spent much labour in the endeavour to trace the plant that bore these seeds. Were it not that good fortune is the determining factor for success in quests of this kind, I am confident that his patience and good judgement would have been rewarded long ago. Finally, I have to acknowledge grants towards the purchase of specimens from the Fossil Botany Committee of the British Association for the Advancement of Science.

1 A resemblance not overlooked by Mr. Arber (loc. cit.). This seed, in view of the correspondence of characters, has been here assigned to the genus Physostoma (see p. Ioz). 


\section{SUMMARY.}

The paper gives a full description of the Coal-Measure seed Physostoma elegans. It is a small straight seed about 6 millims. long by $2 \frac{1}{4}$ millims. across the widest part, and shows many points of agreement with Lagenostoma. The integument, which is ribbed, is coalescent with the nucellus, except at the apex, where the ribs separate to form a whorl of ten tentacles surrounding the pollen-chamber. Ribs and tentacles alike are adorned with long tubular hairs reaching a length of nearly $\frac{1}{2}$ millim.; these hairs give all sections of the seed a very characteristic appearance. It is thought probable that this multiple character of the integument is an archaic feature of which traces are discernible in Lagenostoma and allied seeds. The vascular system, which is very delicate, agrees generally with that of Lagenostoma. The nucellus is represented by a zone rich in secretory sacs, and a well-marked tapetum is also present. The megaspore is peculiar in possessing an apical papilla which protrudes into the floor of the pollenchamber. It may be compared with the 'tent-pole' found in Ginkgo, and many Cordaitean seeds. The pollen-chamber is rich in pollen-grains which show traces of an internal cell-reticulum. Inside the pollen-grains, and associated with them, bodies have been detected which may be regarded as fossilized spermatozoids.

A comparison of Physostoma with seeds of the Lagenostoma-group shows numerous common features. Reasons are given for regarding Physostoma as the most primitive seed that has yet come to light. The plant that bore it has not been traced, but it may be referred provisionally to the Lyginodendreae.

University COLlege, London, October 1908.

\section{EXPLANATION OF PLATES V, VI, AND VII.}

Illustrating Professor F. W. Oliver's paper on Physostoma elegans.

W. = Williamson Collection. S. = Scott Collection. U. C. L., R. and K. = University College, London, Collection. B. = Professor Bottomley's Collection. M. H. = Professor Bertrand's Collection.

\section{PLATE V. Figs. I-I 2 (Photographs).}

Figs. I, 2, and 3. Series of three transverse sections of one seed, from preparations lent by Professor Bertrand. $\times 37$. For explanation of references see under Fig. 4.

Fig. I, near the chalaza, shows the ribs of the integument in the lower half only; the lacunae accompanying the vascular strands are distinct below, confluent above; within follow the secretory zone and the tapetum; the circular space in the centre is the embryo-sac. M. H. 369 (see p. 79).

Fig. 2, across the middle of the seed, shows clearly the ribs of the integument, the vascular 
strands, and the lacunae; the secretory zone is much narrower than in the previous photograph, and the tapetum is unusually distinct; lying in the central space is the contracted prothallus, which is limited by a very delicate membrane (m.g.). M. H. 370 (see pp. $8 \mathrm{I}$ and 97 ).

Fig. 3. Across the apex, showing ten tentacles (with tubular hairs) surrounding the top of the pollen-chamber. The lower tentacles are cut transversely, the upper series somewhat obliquely and nearer to their insertions. l. lacuna accompanying vasc. strand; $p$. pollen-chamber; $p s$. female prothallus; $t$. tentacle; $t$. tentacle out of place; $t . h$. tubular hairs; $t p$. tapetum; s.z. secretory zone; v.b. xylem strand. M. H. $37 \mathrm{I}$ (see pp. 82,91 ).

Fig. 4. Median longitudinal section through the seed-apex. The insertions of two tentacles are shown on the right and left $\left(t_{c}, t_{5}\right) ; t_{1}, t_{2}, t_{3}$, and $t_{4}$, other tentacles seen in section; numerous tubular hairs are present on the tentacles-well shown to the left of $t_{0} ; p$. pollen-chamber-with a pollen-grain on the right-hand side; $s n$. space or sinus between pollen-chamber wall and inner side of tentacle; $x$. fracture in wall of nucellus below pollen-chamber; the large central cavity is the embryo-sac or megaspore chamber, which tapers into a papilla above. U. C. L., R. 92 (Shore). $\times 37$ (see p. 87 ).

Fig. 5. A portion of the wall of the seed on the right of Fig. 2, enlarged. Two ribs, $r^{1}$ and $r^{2}$, are shown, the cells of the filling-tissue with contracted vesicles. "Corresponding with the ribs are two lacunae (l.) and vascular strands (v.b.). Between the bundles the cells of the integument show a well-marked arrangement in radial files $(r . f$.$) . Within the bundles is the secretory zone (s.z.),$ with special development on the bundle radii, and within this the tapetum (tp.), about five cells deep. M. H. $370 . \times 64$ (see pp. 89,98 ).

Fig. 6. A single rib from the wall of the seed, from the top right-hand side of Fig. 2, enlarged. The xylem strand $(v . b$.$) , which is slightly displaced, is well shown. Other references as in Fig. 5$ (see p. 96).

Fig. 7. Several tentacles from the lower side of Fig. 3, enlarged. The interlocking of the epidermal cells where the tentacles are in contact is well shown. $t . h$. tubular hairs of the epidermis ; $e$. small-celled epidermis; l. lacuna. No-traces of the vascular strands are preserved. M. H. 37 I. $\times 64$ (see pp. 87,89 ).

Fig. 8. An oblique section across the pollen-chamber region of a seed. Above are six tentacles entirely free; below four ribs not yet separated. The tubular hairs $(t . h$. $)$ with dark contents are especially well shown on the tentacles. p.c. pollen-chamber (the upper edge of the section passes below its orifice); $m s$. apical papilla of megaspore; s.z. sacs of the secretory zone crowded together below the cavity of the megaspore; $v . b$. xylem strands of the ribs-the dark spots near them are detached secretory sacs. U. C. L., R. 93 (Shore). $\times 37$ (see pp. 88, 98).

Fig. 9. Part of transverse section from about the middle of a seed showing ribs, lacunae (\%) and tubular hairs $(t . h$.$) . The tapetum (tp.) has separated from the zone of secretory sacs (s.z.).$ The cells of the integument show the 'thick' type of preservation. U. C. L., R. 9I (Dulesgate). $\times 40($ see p. 89$)$.

Fig. 10. An oblique tangential section through the upper part of a seed. The plane of section, starting from a point well below the middle of the seed, proceeds obliquely upwards through the embryo-sac (mg.s.); at the apex it strikes the wall of the megaspore papilla (mg.p.), which it cuts tangentially. It emerges close to the orifice (o.p.c.) of the pollen-chamber (p.c.). U. C. L., R. 94 (Dulesgate). $\times$ Io

Fig. II. Part of an oblique section across the apex of a seed. The circular space at the top is the pollen-chamber (p.c.) ; four tentacles are cut very tangentially, the plane of section traversing the investment of tubular hairs $(t . h$.$) close to the body of the tentacles. U. C. L., R. 70, c$ (Shore). $\times 37$ (see p. 88).

Fig. I 2. A tangential section through the apex of a seed. The plane of section falls outside the apical papilla of the megaspore, so that the pollen-chamber (p.c.) appears as a broad, oval cavity. Several tentacles $(t$.$) and groups of tubular hairs \left(t . h_{.}\right)$are cut through. $s$. sinus between pollenchamber and tentacles; $p l$. plinth. S. I 753 (Dulesgate). $\times$ I5 (see p. 90).

\section{PLATE VI. Figs. I3-23 (Drawings).}

Fig. I3. Transverse section of a seed with twelve ribs just below the level at which the tentacles separate. At the top of the figure the sinus $(s n$.) is visible, and in this region the secretory sacs have disappeared from the tissue of the ribs. s.z. secretory zone; tp. tapetum; l. lacuna; v.b. xylem strand. U. C. L., R. 95 (Shore). $\times 34$ (see pp. $85,90,98$ ). 
Fig. I4. Portion of transverse section cut low down in seed, so that the embryo-sac appears filled with tapetal tissue $(t p$.$) ; s.z. zone of secretory cells, projecting at places beyond the vascular$ strands $\left(\boldsymbol{v} . b_{\text {. }}\right) ; l$. lacuna between integument (int.) and secretory zone: it is continuous at this level of the seed. U. C. L., R. 7 I $a$ (Shore). $\times 66$ (see pp. 97, 99).

Fig. I5. Transverse section of a somewhat compressed seed. Seven of the tentacles are free, whilst the four ribs at the bottom of the drawing are still confluent. The section is cut through the lower part of the pollen-chamber (p.c.), which contains several pollen grains, but to the right and below it passes out through the floor. $s n$. sinus; $m g$. cavity of megaspore. The section is cut slightly above that given in Fig. 13. S. 1907 (Dulesgate). $\times 36$ (see p. 85).

Fig. I6. An oblique tangential section through the outer side and hairy covering of a tentacle. The upper two-thirds of the figure represents the sections of the tubular hairs belonging to the distal part of the tentacle. The hairs stand in longitudinal rows-well shown by the third row from the left-hand edge. $t$. filling tissue of tentacle; ep. epidermal cells; t.h. tubular hairs. U. C. L., R. $70, c$ (Shore). $\quad \times 60$ (see p. 88).

Fig. 17. Median longitudinal section of the apex showing the orifice of the pollen-cham er (o.p.c.). On the left the insertion of the pollen-chamber wall has broken away from the nucellus. Five tentacles are shown above cut through in various directions. tp. s.z. black crust representing the tapetal and secretory zones. U. C. L., R. 90 (Shore). $\quad \times 20$ (see pp. 90, 9I).

Fig. 18. Median longitudinal section through an entire seed. The outer part of the integument is wanting except on the right, above. The pollen-chamber and its orifice (o.p.c.) are well shown, also the projecting papilla of the megaspore $(m g \cdot p$.$) . On the left of the concave floor of the pollen-$ chamber traces of the cushion are visible $(\boldsymbol{c u}.) ; s n$. sinus. Above the pollen-chamber are portions of tentacles. S. I 798.(Dulesgate). $\quad \times \mathrm{I}_{4}$ (see pp. $85,90,9 \mathrm{I}$ ).

Fig. I9. Oblique section between seed-base and embryo-sac, showing ring of xylem-strands not yet separated (vb.r.); within this ring are crowded secretory sacs (s.s.) and a few stray ones outside. U. C. L., R. $73, c$ (Shore). $\quad \times 4^{6}$ (see pp. 96, 97).

Fig. 20. Tangential section of the base of a seed. v.b. four vascular strands diverging from point of entry; s.z. zone of secretory sacs. W. 1440 (Moorside). $\times 16$ (see p. 96).

Fig. 2I. Longitudinal section of seed-base-almost median. The divergent bundles $(\boldsymbol{v} . b$.$) enter$ at the base; around them the well-marked lacuna (l.); int. tissue of integument; s.z. secretory zone. U. C. L., R. 96 (Bacup). $\quad \times 40$ (see pp. 8I, 90, 96).

Fig. 22. Oblique tangential section through the base of a seed just grazing the embryo-sac. $t p$. tapetal layer; s.z. zone of secretory sacs; v.b. three xylem strands diverging; l. lacuna; int. tissue of integument; above are traces of three ribs and tubular hairs $(t . h$.$) cut transversely.$ U. C. L., R. $7^{2}, a$ (Shore). $\quad \times 3^{2}$ (see pp. 88,90 ).

Fig. 23. Transverse section across lower part of seed showing curiously preserved tapetum. $t p .1$ outmost layer of tapetum showing cellular characters as in the best preserved specimens; $t p .{ }^{2}$ inner structureless zone of tapetum, where the cells have collapsed; $t p .{ }^{3}$ peculiar striated type of preservation-very commonly fringing the embryo-sac: the striae are readily mistaken for tracheal sculpturing; s.s. secretory sacs. U. C. L., R. 74, $a$ (Shore). $\quad \times 200$ (see p. 98).

\section{PLATE VII. Figs. 24-30 (Drawings).}

Fig. 24. Section through the tapetal zone from near the base of a seed : the radial files of cells, though distorted, are manifest. i.s. inner margin bordering on the embryo-sac; o.s. outer margin bordering on the secretory zone. U. C. L., R. $9^{8}$ (Dulesgate). $\quad \times 180$ (see p. 98 ).

Fig. 25. Oblique transverse section across a pollen-chamber showing the tapetum of the apical papilla of the embryo-sac in a dilapidated state. p.c. pollen-chamber; tp. tapetum, torn and distorted ; c.a.p. cavity of apical papilla. U. C. L., R. 97 (Shore). $\quad \times 86$ (see p. 99).

Fig. 26. Transverse section of a portion of a tentacle showing the epidermis and filling tissuethe cells of the latter with contracted vesicles. i.e. epidermis of inner (adaxial) side; th. proximal ends of tubular epidermal hairs on convex (abaxial) side ; f.t. filling tissue; $l$. lacuna. The vascular strand is not preserved. U. C. L., R. $75, d$ (Shore). $\times 200$ (see pp. 88, 89, 97).

Fig. 27. Part of scalariform tracheal element. S. I 753 (Dulesgate). $\times 400$ (see p. 96).

Fig. 28. Transverse section of a vascular strand with the accompanying lacuna and tissues-from the mid-height of a seed. tp. tapetum; s.z. secretory zone ; $v . b$. xylem strand ; $l$. lacuna; r.f. cells 
of integument below a furrow showing radial seriation. U. C. L., R. 100 (Shore). $\times 100$ (see pp. 96, 98).

Fig. 29. Transverse section of an undersized seed cut about two-thirds up from the base. The most striking feature is the tapetum $(t p$.$) , which has almost entirely separated from the external$ tissues. The right-hand end of the figure shows the ribs at a somewhat higher level than the lefthand end. v.b. vascular strands, which stand well away from the tapetum. U. C. L., R. 99 (Shore). $\times 32$ (see pp. 99, 100).

Fig. 30. Group of pollen-grains and bodies supposed to be spermatozoids. Three pollen-grains $(a, b$, and $c)$ are shown, and a cell-reticulum $d$, presumed to be the remains of a fourth pollen-grain ; $b$ contains two spermatozoids and $c$ one : two others are present, one in contact with $d$, the other between $d$ and $b$. B. 17 (Shore). $\times 380$ (see p. 94). 


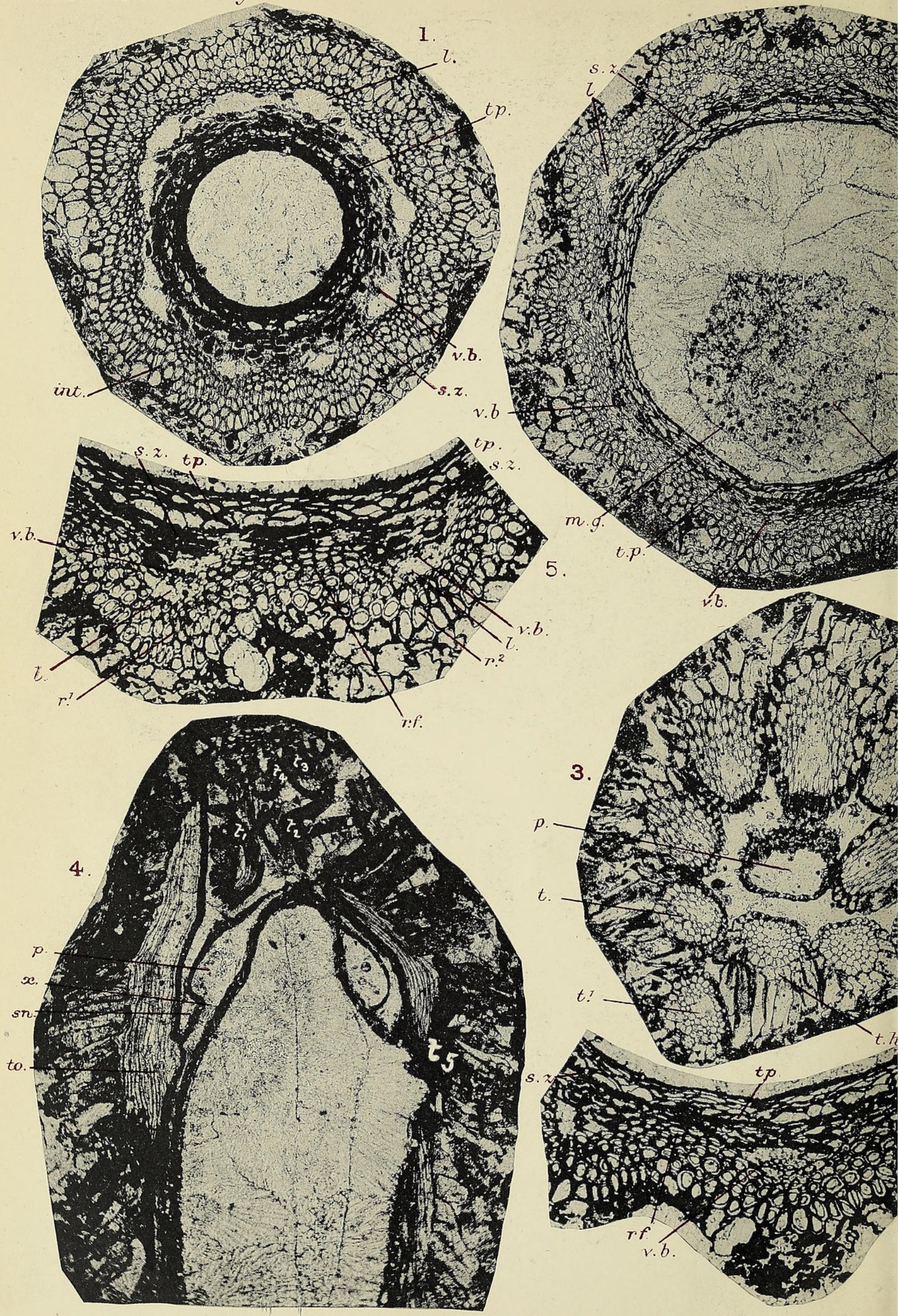



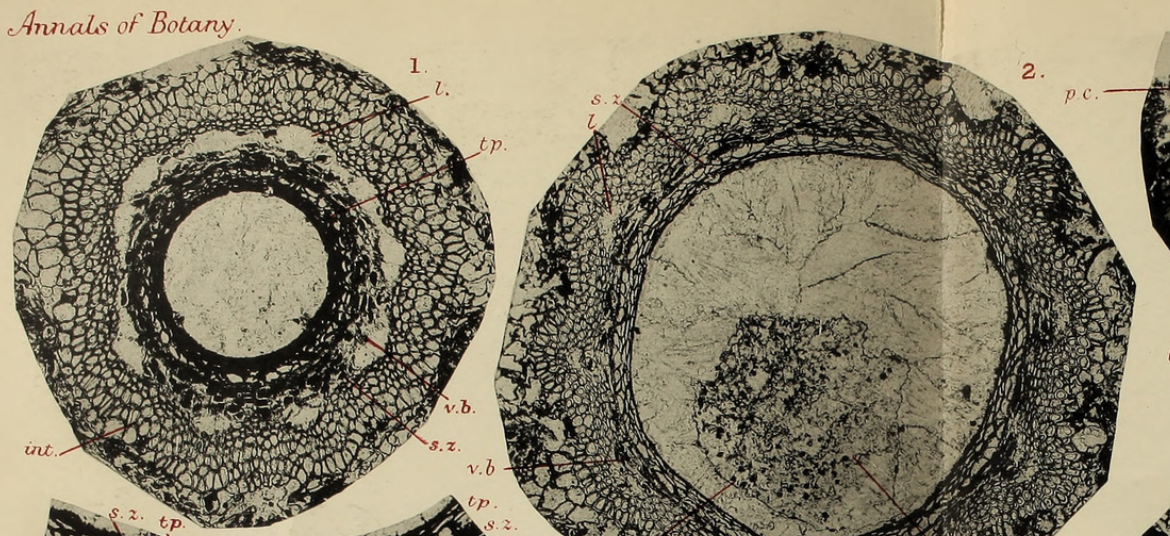

s.

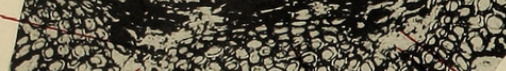

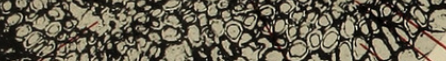

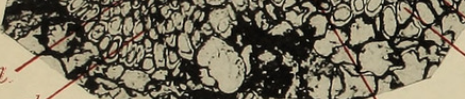
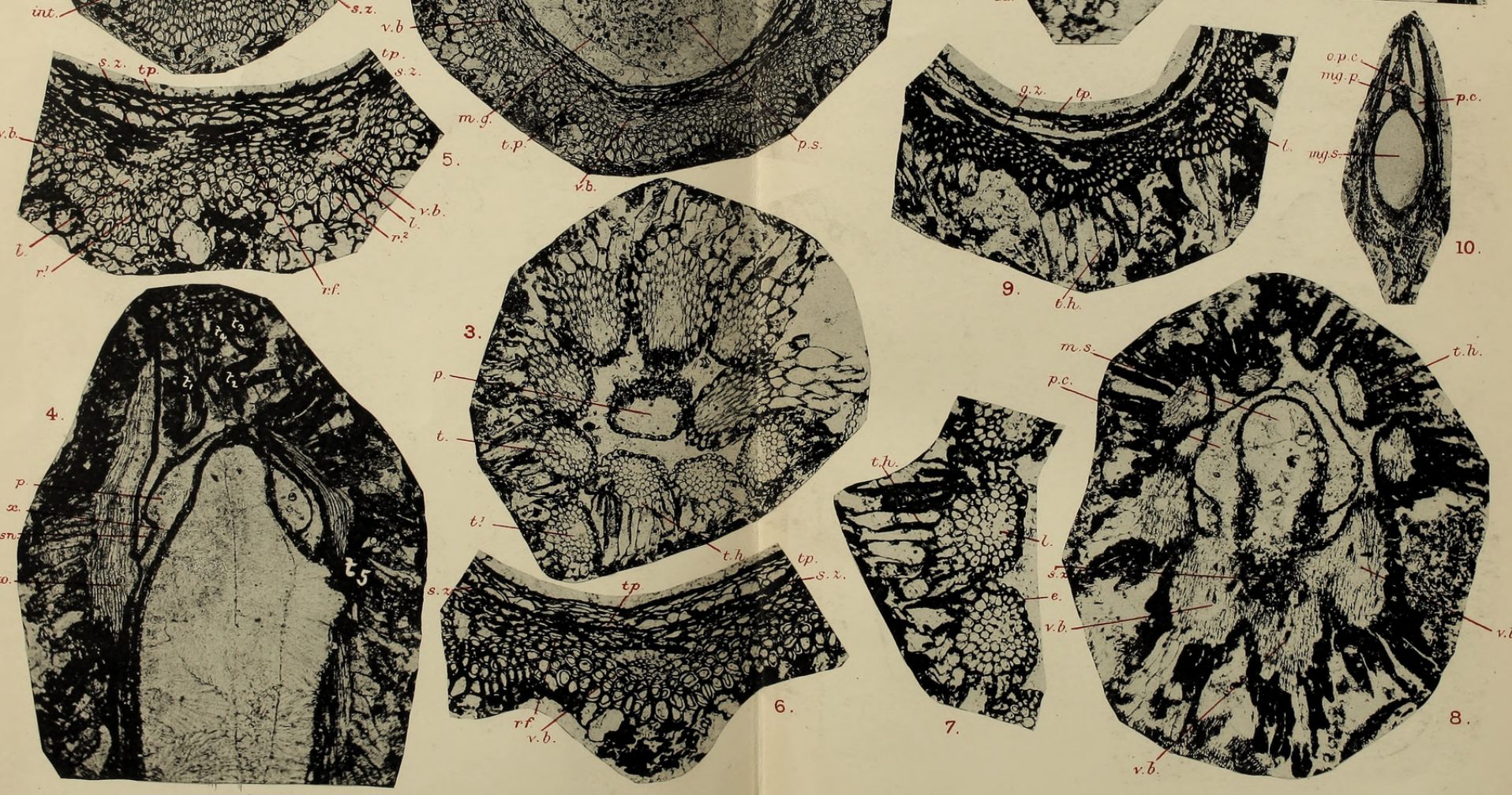

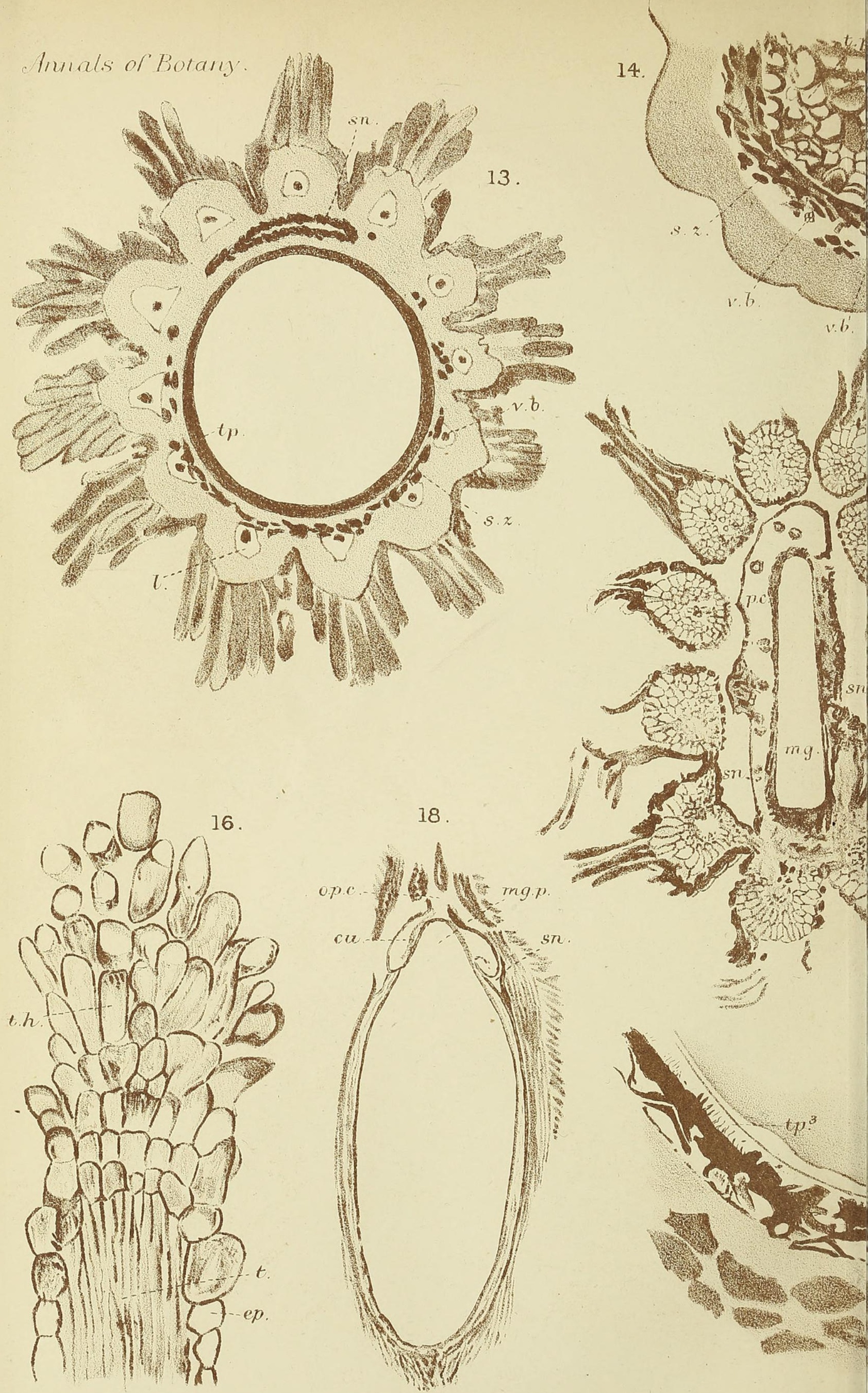

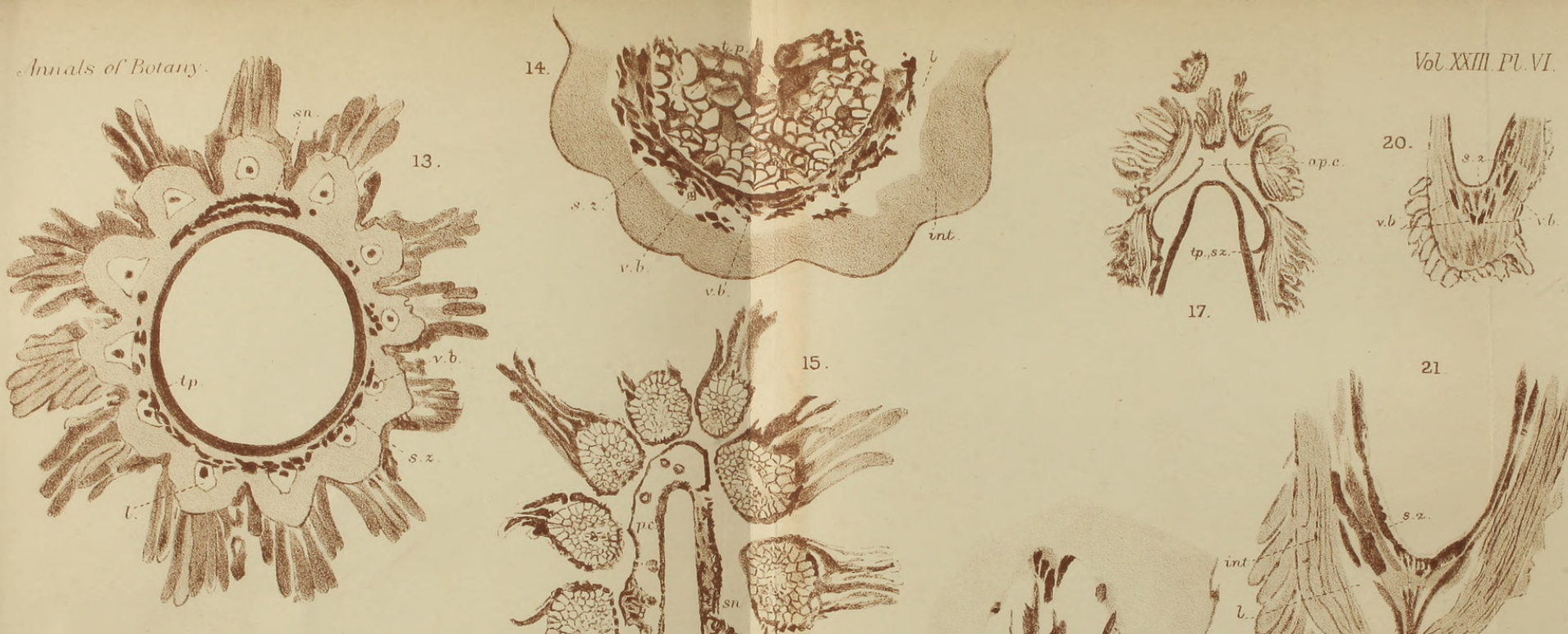

14
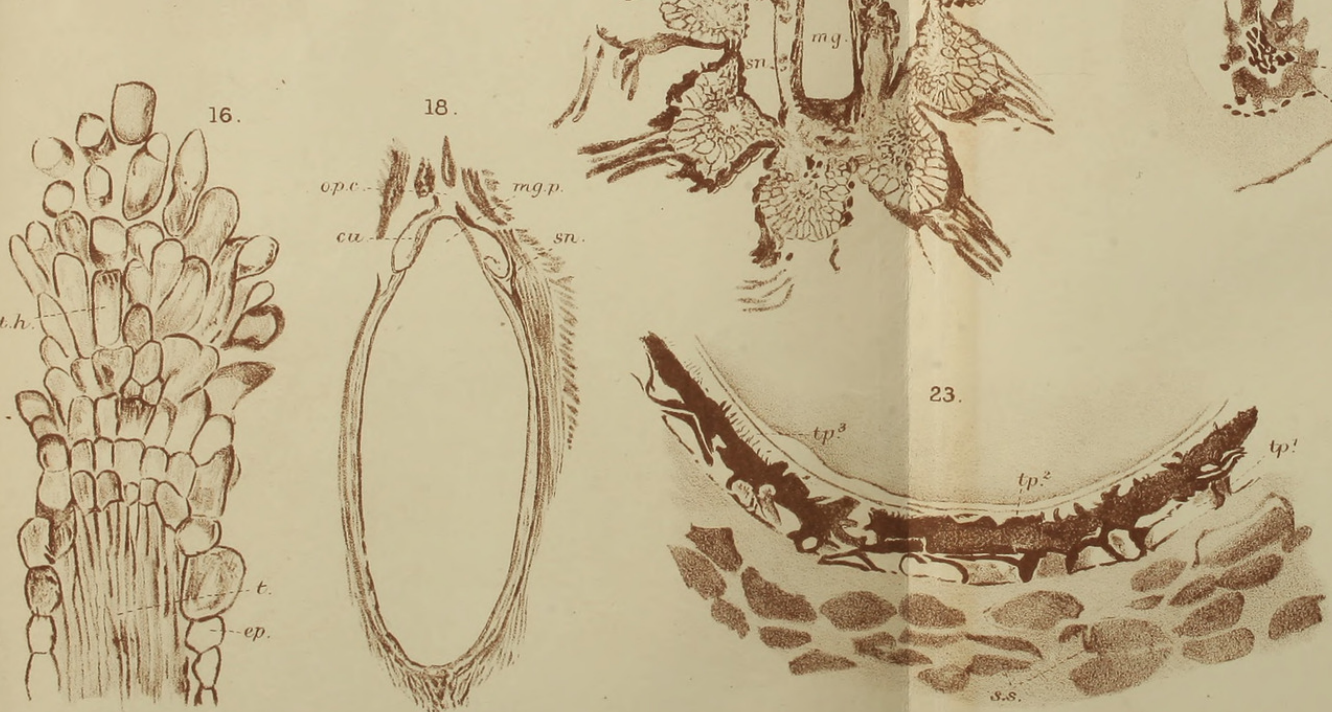

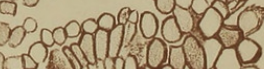

8060 mantan

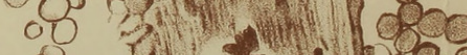

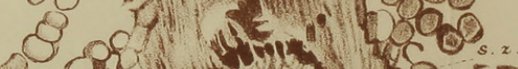

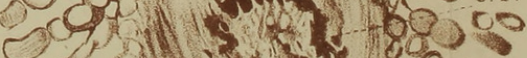
f s Vuly 890 tp.

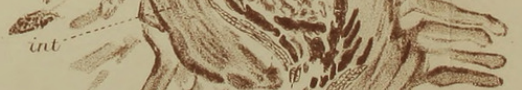
22. 

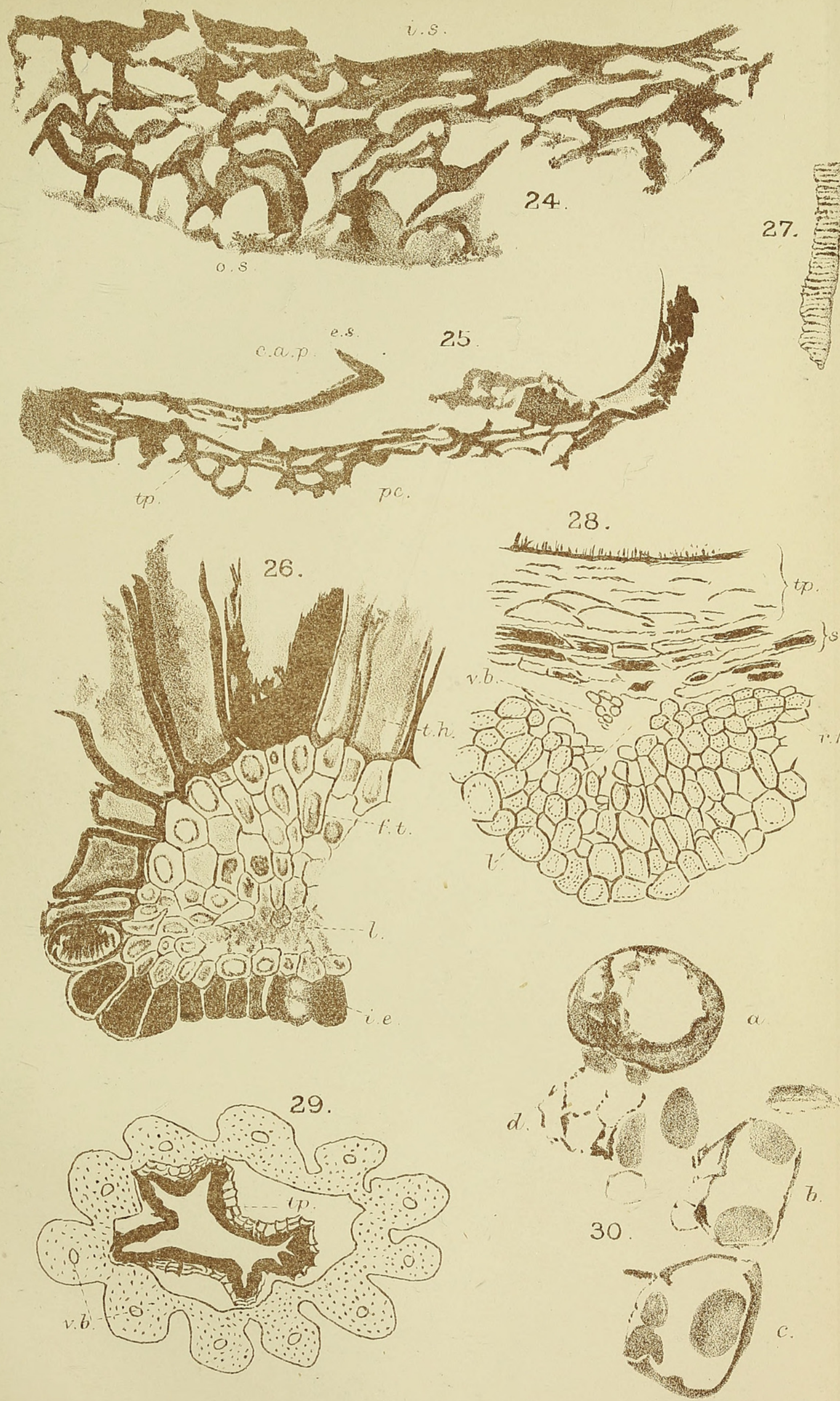


\section{$2 \mathrm{BHL}$ Biodiversity Heritage Library}

Oliver, Francis Wall. 1909. "On Physostoma elegans, Williamson, an archaic type of seed from the palaeozoic rocks." Annals of botany 23, 73-116. https://doi.org/10.1093/oxfordjournals.aob.a089208.

View This Item Online: https://www.biodiversitylibrary.org/item/236540

DOI: https://doi.org/10.1093/oxfordjournals.aob.a089208

Permalink: https://www.biodiversitylibrary.org/partpdf/318940

\section{Holding Institution}

Smithsonian Libraries

\section{Sponsored by}

Biodiversity Heritage Library

\section{Copyright \& Reuse}

Copyright Status: Not in copyright. The BHL knows of no copyright restrictions on this item.

This document was created from content at the Biodiversity Heritage Library, the world's largest open access digital library for biodiversity literature and archives. Visit BHL at https://www.biodiversitylibrary.org. 